\title{
Glacier runoff and its impact in a highly glacierized catchment in the southeastern Tibetan Plateau: past and future trends
}

\author{
Yong ZHANG, ${ }^{1,2}$ Yukiko HIRABAYASHI, ${ }^{2}$ Qiao LIU, ${ }^{3}$ Shiyin LIU $^{1}$ \\ ${ }^{1}$ State Key Laboratory of Cryospheric Sciences, Cold and Arid Regions Environmental and Engineering Research Institute, \\ Chinese Academy of Sciences, Lanzhou, China \\ ${ }^{2}$ Institute of Engineering Innovation, The University of Tokyo, Tokyo, Japan \\ ${ }^{3}$ Institute of Mountain Hazards and Environment, Chinese Academy of Sciences, Chengdu, China \\ Correspondence: Yong Zhang <zhangy@lzb.ac.cn>
}

\begin{abstract}
We investigate past and future trends in glacier runoff and the associated hydrological impacts on river runoff in the Hailuogou catchment, a highly glacierized catchment with extensive debris cover in the southeastern Tibetan Plateau, using a catchment-scale glacio-hydrological model. Past trends in various runoff components of the catchment indicate that glacier runoff has been a large component of total runoff, contributing $\sim 53.4 \%$ of total runoff during the period 1952-2013. Future changes in runoff calculated using the outputs of ten global climate models for representative concentration pathway (RCP) 4.5 and RCP8.5 reveal that glacier runoff plays different roles in the water supply of the catchment for the two RCPs, and the discrepancies between the two RCPs increase in the second half of this century, leading to a considerable difference in the hydrological regime of the catchment. In particular, changes are more remarkable under RCP8.5, under which all glaciers are projected to retreat dramatically and total runoff to decrease slightly by the end of this century. An experimental analysis, in which no debris cover is assumed on glacier ablation zones, indicates that excess meltwater from the debris-covered area provides an $8.1 \%$ increase in total runoff relative to the no-debris assumption case.
\end{abstract}

KEYWORDS: debris-covered glaciers, energy balance, glacier discharge, glacier hydrology, mountain glaciers

\section{INTRODUCTION}

Glaciers on the Tibetan Plateau (TP) and its surroundings are crucial sources of water for Asia's glacier-fed catchments (Cruz and others, 2007; Immerzeel and others, 2010; Kaser and others, 2010) but are largely retreating and losing mass (Yao and others, 2012; Gardner and others, 2013). The role of these glaciers in maintaining regional water resources, which depends principally on the glaciated proportion of catchments (Kaser and others, 2010), may be altered significantly by ongoing changes in glacier extent and volume (Jansson and others, 2003; Casassa and others, 2009). In the TP, continued glacier retreat and mass loss (Yao and others, 2012; Gardner and others, 2013), particularly the accelerated mass loss that has been projected (e.g. Radić and Hock, 2011; Marzeion and others, 2012; Hirabayashi and others, 2013), have raised concerns about the sustainability of water supplies and resulting implications for water resource management and climate adaptation in these catchments.

Many current studies on assessments of glacier changes and their associated hydrological impacts in the TP have focused mainly on the Hindu Kush-Himalayan glacierized catchments (e.g. Rees and Collins, 2006; Immerzeel and others, 2013; Fujita and Sakai, 2014; Lutz and others, 2014), but such research is limited for the southeastern TP. Across the southeastern TP there are a large number of maritime glaciers (Fig. 1), with a total area of $13200 \mathrm{~km}^{2}$ (Shi and Liu, 2000). These glaciers represent $\sim 22 \%$ of the total glacier area of China (Shi and Liu, 2000) and have approximately the same area as the Southern Patagonia Icefield (Rignot and others, 2003). These maritime glaciers are more sensitive to ongoing climate warming in the TP than to changes in the amount of precipitation (Shi and Liu, 2000; Su and Shi, 2002; Fujita, 2008; Zhang and others, 2012) and have exhibited the most significant shrinkage of all retreating glaciers in the TP over recent decades (Su and others, 1992; Pan and others, 2012; Yao and others, 2012). An investigation based on comprehensive in situ data revealed that glacier length in this region decreased at a rate of $48.2 \mathrm{~m} \mathrm{a}^{-1}$ and glacier area decreased at a rate of $0.57 \% \mathrm{a}^{-1}$ from the 1970 s to the 2000 s, representing rates significantly higher than those in other regions of the TP (Yao and others, 2012). One distinctive characteristic of some maritime glaciers is that they are covered by a supraglacial debris cover ( $\mathrm{Li}$ and Su, 1996; Yang and others, 2010; Zhang and others, 2011). Supraglacial debris cover significantly affects ice melting and spatial patterns of mass loss by altering the surface energy balance and imposing a barrier between the atmosphere and the ice (Østrem, 1959; Nakawo and Young, 1981; Mattson and others, 1993), with important consequences for glacier runoff and its contribution to water availability. Realistic prediction of future glacier runoff and its hydrological impact at the catchment scale should therefore account for the debris-cover effect that accelerates (if debris is thin) or suppresses (if it is thick) ice melting beneath debris relative to melting of exposed snow and ice (Østrem, 1959; Nakawo and Young, 1981; Mattson and others, 1993). However, due to lack of information on the detailed spatial distribution of debris thickness and its properties, current investigations on assessments of the hydrological consequences of future glacier changes in the glacierized catchments have neglected the debris-cover 


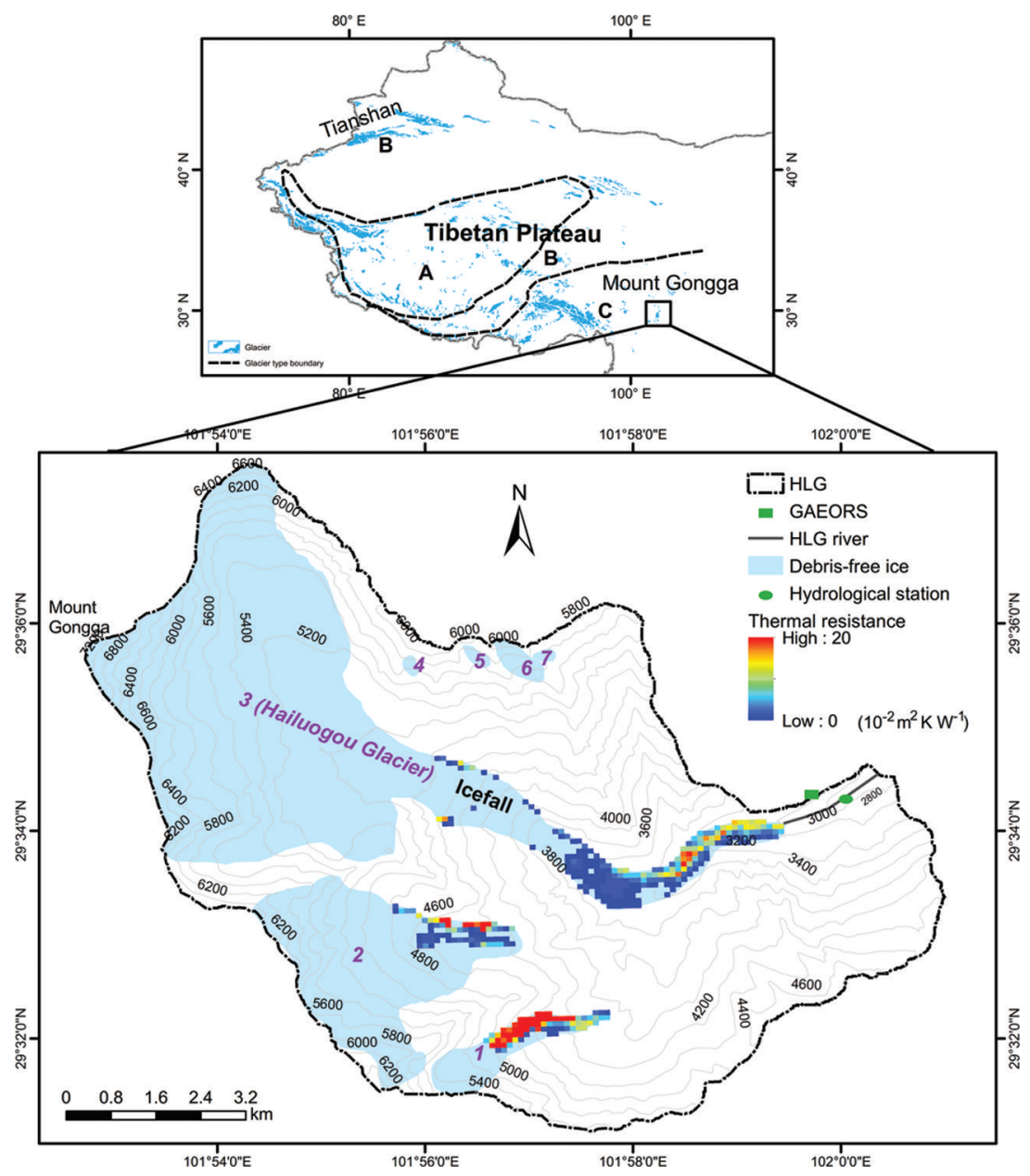

Fig. 1. Map of the Hailuogou (HLG) catchment on the eastern side of Gongga mountain, southeastern TP, with spatial distribution of the thermal resistance of the debris layer. Seven glaciers are named from Glacier No. 1 to Glacier No. 7, and the largest (No. 3) is called HLG glacier. GAEORS denotes the Gongga Alpine Ecosystem Observation and Research Station. Circle marks the hydrological station of GAEORS for runoff observation. A, B and C are extremely continental, subcontinental and monsoonal maritime glaciers, respectively; their boundaries are extracted from Shi and Liu (2000).

effect (e.g. Bliss and others, 2014) or simply addressed it by using a degree-day approach with a multiplicative reduction factor or with different melt factors (e.g. Immerzeel and others, 2013; Lutz and others, 2014). Additionally, the timing of other runoff components (e.g. rainfall runoff, seasonal snowmelt and base flow) is similar to that of the glacier runoff hydrograph owing to the coincident periods of the melt season and heaviest rainfall ( $\mathrm{Li}$ and $\mathrm{Su}, 1996$; $\mathrm{Su}$ and Shi, 2002; Cheng and others, 2004), so these may provide an important contribution to river runoff in the catchments of this region. To better assess the degree of glacier change and subsequent change in glacier runoff in the southeastern TP, we should therefore consider the variation in the contribution of each of the various runoff components to the total runoff and its response to climate change. Nevertheless, quantifying the contribution of glacier runoff in a catchment remains a challenge, as it requires more integrative methods that can address changes in all runoff components and accurately represent the surface mass-balance distribution, complex glacier topography, and physical mechanisms of ice melt under debris mantles.

Here we integrate a catchment-scale surface energy-/ mass-balance model and a hydrological model to explore past and future trends in glacier runoff and their associated hydrological impacts in a glacierized catchment of the southeastern TP with extensive debris cover on the ablation zones. All major glacio-hydrological processes in the catchment are taken into account in the model, which, in particular, accounts for the spatial characteristic of debris cover and its influence on the melting rate of the underlying ice. This study has two objectives. We first quantify the current contribution of glacier runoff to the total runoff and its corresponding role in the present-day hydrological regime of the catchment. Second, we investigate how changes in future glacier runoff and its contribution will affect the magnitude and timing of catchment river runoff under future climate scenarios. This study provides insight into the question of whether it is necessary to account for glacier changes and their effects when assessing the impacts of climate change on water availability in the southeastern TP with coincident periods of melt season and heaviest rainfall.

\section{STUDY AREA}

We chose the Hailuogou (HLG) catchment, located on the eastern slope of Gongga mountain in the southeastern TP $\left(29.6^{\circ} \mathrm{N}, 101.9^{\circ} \mathrm{E}\right.$; Fig. 1$)$, as our study site. It offers us the opportunity to study a maritime glacier system with debris-covered and debris-free glaciers for which longterm, specific, although incomplete, information about the 
Table 1. Summary of the physical parameters used in this study

\begin{tabular}{|c|c|c|}
\hline Parameter & Numerical value & Unit \\
\hline Temperature lapse rate & -4.3 & ${ }^{\circ} \mathrm{Ckm}^{-1}$ \\
\hline Precipitation gradient & 18.0 & $\%(100 \mathrm{~m})^{-1}$ \\
\hline Specific heat capacity of air & 1006 & $\mathrm{~J} \mathrm{~kg}^{-1} \mathrm{~K}^{-1}$ \\
\hline Bulk coefficient for debris-free surface & 0.002 & dimensionless \\
\hline Bulk coefficient for debris-covered ice & 0.005 & dimensionless \\
\hline Latent heat of evaporation of water & $2.50 \times 10^{6}$ & $\mathrm{Jgg}^{-1}$ \\
\hline Latent heat of fusion of ice & $3.34 \times 10^{-5}$ & $\mathrm{~J} \mathrm{~kg}^{-1}$ \\
\hline Density of ice & 900 & $\mathrm{~kg} \mathrm{~m}^{-3}$ \\
\hline Threshold temperature for $P_{\mathrm{S}}$ and $P_{\mathrm{L}}$ & 2.0 & ${ }^{\circ} \mathrm{C}$ \\
\hline Scaling parameter $\left(c_{\mathrm{A}}\right)$ & 0.2055 & $\mathrm{~m}^{3-2 \gamma}$ \\
\hline Scaling parameter $(\gamma)$ & 1.375 & dimensionless \\
\hline Scaling parameter $\left(c_{\mathrm{L}}\right)$ & 1.7206 & $\mathrm{~m}^{3-2 \gamma}$ \\
\hline Scaling parameter $(q)$ & 2.0 & dimensionless \\
\hline Evaporation efficiency & 0.65 & dimensionless \\
\hline Maximum soil water storage & 0.01 & $\mathrm{~m}$ \\
\hline Curve number & 90 & dimensionless \\
\hline Storage constant for firn & 2.7 & days \\
\hline Storage constant for snow & 0.7 & days \\
\hline Storage constant for ice & 0.2 & days \\
\hline Recession coefficient & 0.90 & $d^{-1}$ \\
\hline
\end{tabular}

glaciology, meteorology and hydrology is available ( $\mathrm{Li}$ and Su, 1996; Cheng and others, 2004; Liu and others, 2010; Zhang and others, 2011). The catchment spans $\sim 80.5 \mathrm{~km}^{2}$ of steep alpine topography at elevations ranging from 2755 to $7556 \mathrm{~m}$ a.s.l. Three debris-covered and four debris-free glaciers (Fig. 1), covering $45.3 \%\left(36.44 \mathrm{~km}^{2}\right)$ of the catchment area, exist in the catchment. About $8.2 \%$ of the total glacier area is covered by supraglacial debris (Zhang and others, 2012), the thickness of which increases from several millimetres of patchy cover in the upper part of the ablation zone to $>1.0 \mathrm{~m}$ at the glacier terminus (Zhang and others, 2011). The mean slope of the catchment is $\sim 36.6^{\circ}$ (Liu and others, 2010), and the glacier-free zone is covered mainly by bare rock with small areas of alpine grass vegetation and forest (Li and Su, 1996).

The climate of the catchment is characterized by the southeast monsoon in summer and westerly circulation in winter (Li and Su, 1996; Su and Shi, 2002). The mean annual air temperature from 1988 to 2013 at the Gongga Alpine Ecosystem Observation and Research Station (GAEORS; $3000 \mathrm{~m}$ a.s.l.; Fig. 1 ) is $4.4^{\circ} \mathrm{C}$, and the mean annual precipitation is $\sim 1.9 \mathrm{~m}$. About $80 \%$ of annual precipitation occurs during May-October ( $\mathrm{Li}$ and Su, 1996; Zhang and others, 2010), coincident with the main melt season, and the precipitation peak occurs in July. Precipitation in the catchment increases with altitude (Cheng and others, 2004; Liu and others, 2010). Runoff in the catchment shows a clear seasonal cycle, with the peak in August. About $80.2 \%$ of mean annual runoff occurs between May and October, and runoff is low in other months.

As a result of increasing air temperature, the glaciers in the catchment have been retreating considerably and losing mass during recent decades (Su and others, 1992; Liu and others, 2010; Zhang and others, 2010, 2012; Pan and others, 2012). The mean annual mass balance during 200109 was $\sim-0.79$ m w.e. (Zhang and others, 2012), comparable to that of glaciers in other regions of the TP (Yao and others, 2012). Accelerated thinning, at a rate of $-1.61 \pm$ $0.6 \mathrm{~m} \mathrm{a}^{-1}$, was observed in the catchment during the period 1989-2009 (Zhang and others, 2010). This thinning rate is

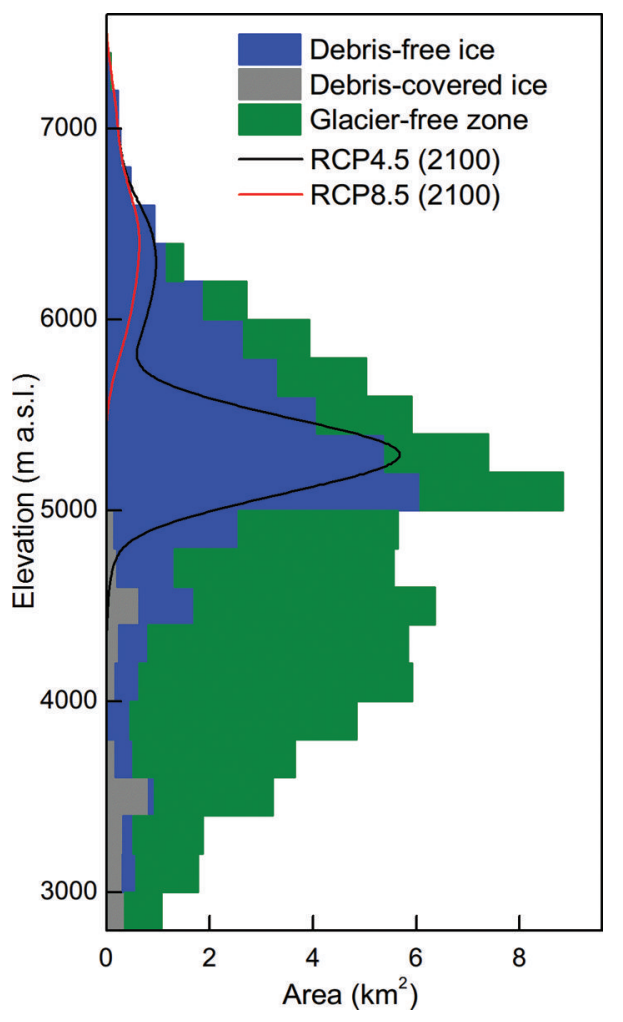

Fig. 2. Area-altitude distributions of the debris-covered and debrisfree surfaces along with the glacier-free zone of the HLG catchment. Black and red lines indicate the multi-model means of projected glacier area-altitude distribution in 2100 under the RCP4.5 and RCP8.5 scenarios, respectively.

rapid compared with rates in other regions of the TP estimated by Gardner and others (2013). The area reductions of seven glaciers have different rates, ranging from $0.09 \% \mathrm{a}^{-1}$ to $1.8 \% \mathrm{a}^{-1}$ (Zhang and others, 2012).

\section{METHODS AND DATA}

\subsection{Catchment discretization}

The HLG catchment is divided into glacier and glacier-free zones based on glacier outlines and a digital elevation model (DEM). The separation of the ablation zones of the three debris-covered glaciers into debris-covered and debris-free surfaces (Fig. 1) follows Zhang and others (2012). Their separation was based completely on the spatial distribution of the thermal resistance of the debris layer derived from remotely sensed data, because the estimated thermal resistance of a debris layer correlates reasonably well with ground-surveyed debris thickness, and its spatial pattern reflects broad-scale variations in debris extent and thickness (Zhang and others, 2011). Each part of the catchment is subdivided at intervals of $50 \mathrm{~m}$ into a set of elevation bands. The area-altitude distributions of the debris-covered/debris-free surfaces along with the glacierfree zone are shown in Figure 2. The physical parameter values and units used in this study are summarized in Table 1.

\subsection{Glacio-hydrological processes}

Runoff from the HLG catchment consists of four possible contributing factors: glacier runoff, rainfall runoff, snowmelt and base flow. Glacier runoff consists of all runoff exiting 
the glacier, including all melt- and rainwater that runs off the glacierized area (Radić and Hock, 2014). Irrespective of glacier runoff, other runoff components are from the glacierfree zone of the catchment. Rainfall runoff consists of the surface runoff from rainfall, runoff from snowmelt consists of the snowmelt released from the snowpack, and base flow is released from the groundwater storage (Neitsch and others, 2011). We calculate these runoff components with a daily time step using a catchment-scale surface energy-/massbalance model for glacier runoff and a simple hydrological model for runoff from the glacier-free zone. The different modelling steps are described in detail in the following.

\subsubsection{Glacier runoff}

Glacier runoff for each elevation band is estimated using the surface energy-/mass-balance model, which is identical to that developed by Zhang and others (2012). The model consists of two coupled components: a surface model that computes the energy available for melting from the exchange of energy between the debris-covered/debris-free surfaces and the atmosphere, and a subsurface model that treats processes occurring in the subsurface after meltwater percolates into the underlying layers. The model particularly accounts for the spatial characteristics of debris cover and the physical mechanisms of ice melt under debris cover. According to the separation used by Zhang and others (2012), glaciers of the catchment were classified into debriscovered and debris-free surfaces. The presence of debris cover on a glacier has a large impact on the surface energy balance as debris cover imposes a barrier between the atmosphere and the ice, which requires a different treatment than that for a debris-free surface. The model solves the surface energy-balance equation to determine the energy available for melting $\left(Q_{M}\right)$ at the debris-free surface, which is given by

$$
Q_{\mathrm{M}}=(1-\alpha) R_{\mathrm{S}}+R_{\mathrm{Ld}}+R_{\mathrm{Lu}}+Q_{\mathrm{S}}+Q_{\mathrm{L}}+Q_{\mathrm{R}}+Q_{\mathrm{G}}
$$

where $R_{\mathrm{S}}, R_{\mathrm{Ld}}, R_{\mathrm{Lu}}, Q_{\mathrm{S}}, Q_{\mathrm{L}}, Q_{\mathrm{R}}$ and $Q_{\mathrm{G}}$ are the downward shortwave radiation flux, the downward longwave radiation flux, the upward longwave radiation flux, turbulent fluxes of sensible and latent heat, the heat flux from rain, and the conductive heat flux into the glacier surface, respectively, and $\alpha$ is the surface albedo. At the debris-covered surface, the conductive heat flux $\left(Q_{G}^{\prime}\right)$ is the only heat flux considered to reach the glacier ice through the debris layer with the simplifying assumption of a linear temperature profile within the debris layer and no heat storage in the debris layer. Hence, the conductive heat flux from the surface toward the debris/ice interface can be described as a function of the surface temperature, the temperature at the interface between debris and ice, and the thermal resistance of the debris layer. Therefore, the energy available for ice melting at the debris-covered surface is calculated as

$$
\left\{\begin{array}{l}
Q_{\mathrm{M}}=Q^{\prime}{ }_{\mathrm{G}}=\left(T^{\prime}{ }_{\mathrm{S}}-T_{\mathrm{I}}\right) / R \\
Q_{\mathrm{G}}^{\prime}=\left(1-\alpha^{\prime}\right) R_{\mathrm{S}}+R_{\mathrm{Ld}}+R_{\mathrm{Lu}}+Q_{\mathrm{S}}+Q_{\mathrm{L}}+Q_{\mathrm{R}^{\prime}}
\end{array}\right.
$$

where $\alpha^{\prime}$ is the albedo of the debris-covered surface, $R$ is the thermal resistance of the debris layer $\left(\mathrm{m}^{2} \mathrm{KW}^{-1}\right), T_{\mathrm{S}}^{\prime}$ is the debris surface temperature $\left({ }^{\circ} \mathrm{C}\right)$, and $T_{1}$ is the ice temperature at the ice-debris surface, which is assumed to be the melting point (Zhang and others, 2011).

All components of the energy balance are defined as positive toward the surface using units of $\mathrm{Wm}^{-2}$, and negative away from the surface. The model computes these fluxes on a daily time step from the meteorological and topographic data. The net shortwave radiation is calculated from the downward shortwave radiation and the surface albedo. However, downward shortwave radiation data are not available for the catchment before 2005, and are estimated by applying the scheme of Zhang and others (2012). They found a favourable correlation between precipitation and atmospheric transmissivity of solar radiation in terms of the monthly mean values. This relationship is used to estimate the daily mean transmissivity from daily precipitation data. The downward shortwave radiation is then calculated from the estimated transmissivity and the incoming shortwave radiation at the top of the atmosphere. Details of this approach are provided by Zhang and others (2012). Snow and debris-covered/debris-free ice albedos are treated individually. Our snow albedo scheme follows that of Yamazaki and others (1993) and Fujita (2007). They suggested that snow albedo is the net result of multiple reflections of broadband shortwave radiation under the assumption that snowpack consists of an ice plate and air layer in the vertical dimension. With their approach, the relevant snow physical property is snow density, which is used to calculate snow specific surface area relevant to the optical properties of snow. Special attention is paid to the maritime glaciers, on which melting and refreezing of snow are likely to be the main cause of short-term density changes through snow compaction ( $\mathrm{Li}$ and $\mathrm{Su}, 1996$ ). Hence, we calculate the albedo using this simplified concept of multiple scattering in an ice plate whose thickness is related to the surface snow density, which changes with snow compaction. This scheme has been validated against observations on different glaciers of the TP (e.g. Fujita and Ageta, 2000; Sakai and others, 2009; Fujita and Nuimura, 2011). The albedos of debris-covered and debris-free surfaces are set to 0.2 and 0.3 , respectively, whereas that of the initial fresh snow is assumed to be 0.8 (Zhang and others, 2012). Downward longwave radiation is estimated from an empirical equation using air temperature, relative humidity and the ratio of solar radiation to the theoretical top-of-atmosphere radiation based on the scheme of Glover and McCulloch (1958) and Kondo (1994). Upward longwave radiation is calculated using the Stefan-Boltzmann equation and the surface temperature, assuming a black body for the snow/ice surface. The turbulent heat fluxes are determined using the bulk formulae, and the heat flux supplied by rain is calculated using an equation suggested by Hay and Fitzharris (1988). These fluxes are calculated as

$$
\begin{aligned}
& Q_{\mathrm{S}}=C_{\mathrm{a}} \rho_{\mathrm{a}} \operatorname{CU}\left(T_{\mathrm{a}}-T_{\mathrm{S}}\right) \\
& Q_{\mathrm{L}}=I_{\mathrm{e}} \rho_{\mathrm{a}} \operatorname{CU}\left[\mathrm{rhq}\left(T_{\mathrm{a}}\right)-q\left(T_{\mathrm{S}}\right)\right], \\
& Q_{\mathrm{R}}=\rho_{\mathrm{w}} C_{\mathrm{w}} \mathrm{W}\left(T_{\mathrm{r}}-T_{\mathrm{S}}\right)
\end{aligned}
$$

where $T_{\mathrm{S}}$ and $T_{\mathrm{a}}$ are the temperatures of the surface and air $\left({ }^{\circ} \mathrm{C}\right)$, respectively, $c_{\mathrm{a}}$ and $\mathrm{C}_{\mathrm{w}}$ are the specific heat capacities of air and water, respectively, $\rho_{\mathrm{a}}$ and $\rho_{\mathrm{w}}$ are the densities of air and water, $C$ is the bulk coefficient for sensible and latent heat, $U$ is the wind speed $\left(\mathrm{m} \mathrm{s}^{-1}\right), l_{\mathrm{e}}$ is the latent heat of the evaporation of water, and $\mathrm{rh}$ is the relative humidity. $T_{\mathrm{r}}$ is the rainfall temperature (which can be approximated by $T_{\mathrm{a}}$ ), and $q$ is the saturated specific humidity $\left(\mathrm{kg} \mathrm{kg}^{-1}\right)$ which is calculated as a function of air temperature using the empirical equations presented by Kondo (1994). All energy-balance components at the glacier surface, except for the shortwave radiation term, are explicitly determined from the surface temperature. Therefore, the surface temperature for the 
debris-free surface is solved to satisfy all heat balance equations by iterative calculation of the conductive heat flux, which is obtained by calculating the temperature profile of the snow layer and/or glacier ice. For the debriscovered surface, the surface temperature is determined numerically by an iterative approach consistent with previous studies of debris-covered glaciers (e.g. Nicholson and Benn, 2006; Reid and others, 2012).

The precipitation phase (snow, rain or sleet) for each elevation band of the catchment is determined using the daily air temperature. A temperature of $2{ }^{\circ} \mathrm{C}$ is used, at or below which precipitation falls in solid form $\left(P_{\mathrm{S}}\right)$ and above which precipitation falls as rain $\left(P_{\mathrm{L}}\right)$. A mixture of snow and rain is assumed within a transition zone ranging from $1 \mathrm{~K}$ above to $1 \mathrm{~K}$ below the threshold temperature. Within this temperature range, the snow and rain percentages of total precipitation are obtained by linear interpolation. This threshold is derived by Liu and others (2009) using longterm in situ observations of precipitation type and air temperature in the southeastern TP. Additionally, redistribution of the original snowfall by wind transport or avalanche is not considered. Therefore, glacier runoff $(D$; defined as all melt- and rainwater without evaporation and refreezing) for each elevation band is obtained as

$$
D=Q_{\mathrm{M}} / I_{\mathrm{f}}+P_{\mathrm{L}}-Q_{\mathrm{L}} / I_{\mathrm{e}}-R_{\mathrm{F}},
$$

where $I_{\mathrm{f}}$ is the latent heat of fusion of ice. The refreezing amount $\left(R_{\mathrm{F}}\right)$ is estimated by considering the conduction of heat into glacier ice, the snow layer, and the presence of water at the interface between the snow layer and glacier ice, which is identical to the estimation developed by Fujita and Ageta (2000). Refreezing during winter and during shorter cooling events is also considered by assuming a maximum water content of $5 \%$ by volume (Zhang and others, 2012).

Glacier runoff is routed through the glacier to the catchment outlet based on a linear reservoir model (Baker and others, 1982), which has been applied widely to route water through glaciers in various regions (Hock and Noetzli, 1997; Escher-Vetter, 2000; Zhang and others, 2007; cf. Hock and Jansson, 2005). The approach assumes that the reservoir volume, $V(t)$, is proportional to its runoff, $Q(t)$, the factor of proportionality being the storage constant, $k$, with units of time. Storage and continuity equations for the reservoir are given by

$$
\begin{aligned}
V(t) & =k Q(t) \\
\frac{\mathrm{d} V}{\mathrm{~d} t} & =R(t)-Q(t),
\end{aligned}
$$

where $R(t)$ is the rate of water inflow to the reservoir, here equivalent to the glacier runoff of each elevation band. According to glacier surface characteristics obtained from field surveys ( $\mathrm{Li}$ and Su, 1996), we subdivide the glaciers into three reservoirs with different storage constants: an ice reservoir, defined as the area of debris-covered and debris-free ice below the mean equilibrium-line altitude (5068 ma.s.l.; Zhang and others, 2012), a firn reservoir, defined as the area above 6000 ma.s.I. (Li and Su, 1996), and a seasonally variable snow reservoir, defined as the snow-covered area outside the firn reservoir.

To capture the feedback between glacier mass balance and changing glacier hypsometry (i.e. changes in volume, surface area and elevation range), volume-area and volume-length scaling (Bahr, 1997; Bahr and others,
1997) are used to adjust glacier length and area-altitude distribution at the end of each mass-balance year. This approach has been widely used to model changes in glacier hypsometry in different studies at different scales (e.g. Radić and others, 2008; Hirabayashi and others, 2010, 2013; Radić and Hock, 2011; Luo and others, 2012; Marzeion and others, 2012). Changes in glacier volume $(\Delta V)$, area $(\Delta A)$ and length $(\Delta L)$ during each mass-balance year are estimated as

$$
\begin{aligned}
& \Delta V(t)=B(t) A_{\mathrm{S}}(t), \\
& \Delta A(t)=\left(\frac{V(t+1)}{C_{\mathrm{A}}}\right)^{1 / \gamma}-A_{\mathrm{E}}(t), \\
& \Delta L(t)=\left(\frac{V(t+1)}{C_{\mathrm{L}}}\right)^{1 / q}-L(t),
\end{aligned}
$$

where $B(t)$ is the specific mass balance during the massbalance year, a sum of surface accumulation, ablation and refreezing, $c_{\mathrm{A}}, C_{\mathrm{L}}, \gamma$ and $q$ are scaling parameters, $A_{\mathrm{S}}(t)$ and $A_{\mathrm{E}}(t)$ are the surface area of the glacier at the start (1 October) and end (30 September the following year) of the massbalance year, respectively, $V(t+1)$ is the glacier volume at the end of the mass-balance year and $L(t)$ is the glacier length at the start of the mass-balance year. The change in glacier length determines the elevation range at the end of the mass-balance year, which is associated with the areaaltitude distribution of the catchment. The area for each elevation band is adjusted at the end of the mass-balance year based on the updated glacier elevation range using a function of the area-altitude distribution derived by Hirabayashi and others (2010, 2013). They applied this function to estimate the past and future mass changes in global mountain glaciers and ice caps.

\subsubsection{Runoff from the glacier-free zone}

For each elevation band of the glacier-free zone, we use the US Soil Conservation System (SCS) curve number method (SCS, 1972), in which the curve number parameter is calibrated, to estimate rainfall runoff. We classify precipitation as rain or snow using the mean daily air temperature. Snowfall is stored at the ground surface in the form of snowpack. The initial snowpack is assumed to be zero at the end of the 1951 melt season. The snowpack will increase with additional snowfall or decrease with snowmelt or evaporation. The mass balance for the snowpack is expressed as

$$
\mathrm{SN}=P_{\mathrm{S}}-Q_{\mathrm{SM}} / I_{\mathrm{f}}-Q_{\mathrm{L}} / l_{\mathrm{e}}
$$

where $\mathrm{SN}$ is the water content of the snowpack (mm w.e.). The energy used for snowmelting $\left(Q_{S M}\right)$ is estimated from the energy balance over the snow surface, as shown in Eqn (1). Potential evaporation in the case of no snow on the glacier-free surface is calculated according to the PenmanMonteith equation (Allen and others, 1998). The PenmanMonteith equation combines components that account for the energy needed to sustain evaporation, the strength of the mechanisms required to remove the water vapour, and aerodynamic and surface resistance terms (Neitsch and others, 2011). This equation was applied to estimate the evaporation for different surfaces in the HLG catchment and adjacent regions in the 1990s, and performed well as judged by comparison of simulated and observed evaporation (Cheng and others, 2004). The equation gives a value under a reference condition, which is used as a basis to estimate 
the actual evaporation. Here actual evaporation is determined by multiplying potential evaporation by evaporation efficiency (Table 1).

The sum of rainfall runoff, actual evaporation, and snowmelt is then added to the soil water storage, and if the maximum soil water storage (Table 1) is exceeded, recharge to the groundwater occurs. Base flow is calculated using the base flow simulation approach in the Soil Water Assessment Tool (SWAT) model. SWAT partitions groundwater into two aquifer systems: a shallow aquifer that contributes to runoff in the watershed and a deep aquifer that contributes to runoff somewhere outside the watershed (Neitsch and others, 2011). This method has been widely applied to different glacierized catchments in the TP (e.g. Luo and others, 2012; Immerzeel and others, 2013; Lutz and others, 2014). SWAT generally uses a quick-reacting reservoir (shallow aquifer storage) approach to simulate base flow (Neitsch and others, 2011). Subsequently, Luo and others (2012) added a slow-reacting linear reservoir to the available quick-reacting reservoir for base flow generation in the SWAT model and applied it to simulate the runoff process in a glacier and snowmelt-dominated basin in the Tien Shan. Their results indicate that a combination of two linear reservoirs leads to the best results in reproducing the streamflow processes. Hence, our base flow scheme follows the base flow simulation scheme of Luo and others (2012). The total base flow $\left(Q_{\mathrm{b}}\right)$ in the scheme of Luo and others (2012) is given by

$$
\begin{aligned}
Q_{\mathrm{b}, t}= & Q_{\mathrm{b}, \mathrm{sh}, t}+Q_{\mathrm{b}, \mathrm{dp}, t} \\
Q_{\mathrm{b}, \mathrm{sh}, t}= & Q_{\mathrm{b}, \mathrm{sh}, t-1} \exp \left(-\alpha_{\mathrm{gw}, \mathrm{sh}} \cdot \Delta t\right) \\
& +W_{\mathrm{rchrg}, \mathrm{sh}, t} \cdot\left[1-\exp \left(-\alpha_{\mathrm{gw}, \mathrm{sh}} \cdot \Delta t\right)\right] \\
Q_{\mathrm{b}, \mathrm{dp}, t}= & Q_{\mathrm{b}, \mathrm{dp}, t-1} \exp \left(-\alpha_{\mathrm{gw}, \mathrm{dp}} \cdot \Delta t\right) \\
& +W_{\mathrm{rchr}, \mathrm{dp}, t} \cdot\left[1-\exp \left(-\alpha_{\mathrm{gw}, \mathrm{dp}} \cdot \Delta t\right)\right]
\end{aligned}
$$

where $W_{\text {rchrg }}$ is the amount of recharge entering the aquifers, the subscripts ' $\mathrm{sh}^{\prime}$ and ' $\mathrm{dp}$ ' indicate the shallow and deep aquifers, respectively, $\alpha_{\mathrm{gw}}$ is the delay time of the overlying geologic formations, $t$ is the number of days, and $\Delta t$ is the step time length. Details of the base flow approach and parameter definitions in SWAT are provided by Neitsch and others (2011) and Luo and others (2012). The delay times for the shallow and deep aquifers and soil parameters (including soil moisture content and maximum soil water storage), derived from field experiments in the HLG catchment and adjacent catchments, were given by Cheng and others (2004). Finally, the total runoff for each elevation band of the glacier-free zone is calculated as the sum of rainfall runoff, snowmelt and base flow and is routed to the catchment outlet using a recession function (Martinec, 1975), in which a recession coefficient is calibrated.

\subsection{Input data}

The model is forced by a combination of local meteorological observations and observation-based global gridded data. The local meteorological forcing data required by the model include air temperature, precipitation, wind speed, relative humidity and the incoming solar radiation at daily time steps observed at GAEORS (Fig. 1). Daily temperature, precipitation, wind speed and relative humidity are available for the period 1988-2013, and incoming solar radiation is available for the period 2005-13. The observation-based global gridded datasets of daily precipitation and near-surface temperature are available for the period
1951-2007 at a spatial resolution of $0.5^{\circ}$. The temperature dataset (Hirabayashi and others, 2008) was generated based on monthly temperature and monthly diurnal temperature ranges of the Climate Research Unit version TS 2.1 data for the period 1951-2002 (CRU; Mitchell and Jones, 2005) and the dataset of Fan and Van den Dool (2008) for the period 2003-07 scaled using the mean ratio of monthly temperatures of CRU and their data from 1986 to 2002. The daily precipitation dataset was created by collecting rain gauge observation data, a long-term continental-scale daily product (Yatagai and others, 2009). The global gridded data were bias-corrected on a daily timescale using linear regression relations established between local observations at GAEORS and gridded data (Zhang and others, 2012). The biascorrected temperature and precipitation correlate well with the corresponding observations from GAEORS, yielding correlation coefficients of 0.96 and 0.87 and root-meansquare error values of $1.5^{\circ} \mathrm{C}$ and $0.001 \mathrm{~m}$, respectively (Zhang and others, 2012). This confirms that the biascorrected gridded data correspond sufficiently well with observed temperature and precipitation from GAEORS. In this study, we directly use the bias-corrected gridded temperature and precipitation data.

To analyse future changes in the variability of glacier runoff and other runoff components under climate change, daily air temperature and precipitation from the latest ten general circulation models (GCMs; Table 2) participating in the fifth phase of the Coupled Model Intercomparison Project (CMIP5; Taylor and others, 2012) are used to project changes in all runoff components of the catchment. Two CMIP5 GCM simulations are employed in this study: historical simulations (1948-2005) forced by natural (e.g. volcanic and solar) and anthropogenic (e.g. greenhouse gases and ozone) forcings and future simulations (20062100) forced by the representative concentration pathway (RCP) scenarios (Van Vuuren and others, 2011). The RCPs span a range of radiative forcing from 2.6 to $8.5 \mathrm{~W} \mathrm{~m}^{-2}$, representing various possible climate outcomes (Moss and others, 2010). Here we only use the results for the moderate RCP4.5 and the most extreme RCP8.5 scenarios.

For each elevation band, the air temperature and precipitation time series are interpolated according to its mean elevation using altitude-dependent lapse rates. The air temperature is assumed to decrease with increasing altitude with a constant lapse rate (Table 1), which was derived from field observations of the catchment (Zhang and others, 2012). Precipitation increases with altitude in the catchment, based on a precipitation gradient (Cheng and others, 2004; Liu and others, 2010). The precipitation gradient (Table 1) was calibrated in the same catchment by Zhang and others (2012). Wind speed observed from GAEORS is not interpolated and is assumed representative for the entire catchment due to its weak correlation with the melt rate (Ohmura, 2001).

Monthly runoff data from the gauge station located at the river outlet of the catchment (Fig. 1) are used to evaluate the model results. Runoff records are available for the period 1994-2007. The area and length of each glacier in the catchment are derived from the Chinese Glacier Inventory (Pu, 1994), which provides pre-1966 information. To estimate the glacier area in different periods, glacier outlines for 1966, 1975, 1994 and 2007 are obtained as shape files from Liu and others (2010). They produced glacier outlines for different periods based on topographic maps and 
remotely sensed data. Information on debris thickness and the spatial distribution of the thermal resistance of the debris layer is derived from Zhang and others (2011, 2012), who carried out extensive in situ surveys of debris thickness on the ablation zone of HLG glacier (Fig. 1) and estimated the spatial distribution of the thermal resistance of the debris layer on the ablation zones of three debris-covered glaciers from remotely sensed data. Additionally, a DEM at a spatial resolution of $90 \mathrm{~m}$, which was produced from aerial photographs acquired in 1989 (Zhang and others, 2010), is used to compute the area of each elevation band and spatially distribute meteorological data.

\subsection{Calibration and validation}

Model calibration involves constraining model parameters to obtain the best fit between the simulated results and the available observed data. The model is initially run using the observed meteorological data from GAEORS for a total of 7 years (1994-2000) to calibrate the parameters of the storage constants for ice, snow and firn, as well as the curve number and the recession coefficient. These parameters are adjusted within ranges based on previously published values to minimize the difference between simulated and observed monthly runoff for the period 1994-2000. The parameters associated with the best agreement between observed and modelled monthly runoff in different years are chosen. After model calibration, the model is evaluated against an independent set of monthly runoff data collected for the time period 2001-07. Additionally, the approach for simulating glacier hypsometry is evaluated by comparing the modelled glacier area with satellite-based observations during different periods.

Using a single criterion in the calibration and validation processes constrains the model parameters to fit certain characteristics of the observed data and neglects the remaining features. Therefore, we adopt multiple criteria to assess the model performance: the Nash-Sutcliffe efficiency (NSE; Nash and Sutcliffe, 1970) and the per cent bias (PBIAS; Moriasi and others, 2007), which are given by

$$
\begin{aligned}
\text { NSE } & =1-\frac{\sum\left[Q_{\text {sim }}(i)-Q_{\text {obs }}(i)\right]^{2}}{\sum\left[Q_{\text {obs }}(i)-\bar{Q}_{\mathrm{obs}}\right]^{2}}, \\
\text { PBIAS } & =\frac{\sum\left[Q_{\mathrm{obs}}(i)-Q_{\mathrm{sim}}(i)\right] \cdot 100}{\sum Q_{\mathrm{obs}}(i)},
\end{aligned}
$$

where $Q_{\text {obs }}$ and $Q_{\text {sim }}$ are the observed and simulated runoff at month $i$, and $\bar{Q}_{\text {obs }}$ is the mean of observed runoff.

NSE is a normalized statistic that determines the relative magnitude of the residual variance compared with the measured variance (Nash and Sutcliffe, 1970). NSE ranges between $-\infty$ and 1.0 ( 1 inclusive), with NSE $=1$ for perfect agreement between observed and simulated. NSE values between 0.0 and 1.0 indicate acceptable performance, whereas values $<0.0$ indicate unacceptable performance. However, NSE tends to an overestimation of model performance during peak flows and an underestimation during low-flow conditions (Legates and McCabe, 1999). PBIAS measures the average tendency of the simulated values to be smaller or larger than observed values, so it can clearly indicate poor model performance. However, over different periods PBIAS can yield an average value close to zero, indicating good model balance, even though there had been extremes (Moriasi and others, 2007). PBIAS $=0$ is the optimal value, with lower-magnitude values indicating more
Table 2. Summary of the ten CMIP5 GCMs selected for this study. The institution and model names are taken from http://cmip-pcmdi. IInl.gov/cmip5/availability.html. Size information is extracted from

\begin{tabular}{|c|c|c|}
\hline Model & Institute & $\begin{array}{l}\text { Number } \\
\text { of grids }\end{array}$ \\
\hline CCCma-CanESM2 & $\begin{array}{l}\text { Canadian Centre for Climate } \\
\text { Modelling and Analysis, Canada }\end{array}$ & $128 \times 64$ \\
\hline CMCC-CM & $\begin{array}{l}\text { Centro Euro-Mediterraneo per i } \\
\text { Cambiamenti Climatici, Italy }\end{array}$ & $480 \times 240$ \\
\hline CNRM-CM5 & $\begin{array}{l}\text { Centre National de Recherches } \\
\text { Météorologiques/Centre Européen de } \\
\text { Recherche et Formation Avancées en } \\
\text { Calcul Scientifique, France }\end{array}$ & $256 \times 128$ \\
\hline GFDL-ESM2G & $\begin{array}{l}\text { Geophysical Fluid Dynamics Laboratory, } \\
\text { USA }\end{array}$ & $144 \times 90$ \\
\hline INM-CM4 & $\begin{array}{l}\text { Institute for Numerical Mathematics, } \\
\text { Russia }\end{array}$ & $180 \times 120$ \\
\hline MIROC5 & $\begin{array}{l}\text { Atmosphere and Ocean Research } \\
\text { Institute, National Institute for } \\
\text { Environmental Studies, and Japan Agency } \\
\text { for Marine-Earth Science and Technology, } \\
\text { Japan }\end{array}$ & $\begin{array}{l}256 \times 128 \\
y \\
,\end{array}$ \\
\hline MPI-ESM-LR & $\begin{array}{l}\text { Max Planck Institute for Meteorology } \\
\text { (MPI-M), Germany }\end{array}$ & $192 \times 96$ \\
\hline MRI-CGCM3 & Meteorological Research Institute, Japan & $320 \times 160$ \\
\hline NCAR-CCSM4 & $\begin{array}{l}\text { National Center for Atmospheric } \\
\text { Research, USA }\end{array}$ & $288 \times 192$ \\
\hline NCC-NorESM1-M & Norwegian Climate Centre, Norway & $144 \times 96$ \\
\hline
\end{tabular}
data headers

accurate model simulation. Positive values indicate model underestimation bias, and negative values indicate model overestimation bias. The two criteria are commonly used in model evaluation. As suggested by Moriasi and others (2007), the modelling performance can be classified as 'very good', 'good', 'satisfactory' or 'unsatisfactory' where $0.75<\mathrm{NSE} \leq 1.0,0.65<\mathrm{NSE} \leq 0.75,0.50<\mathrm{NSE} \leq 0.65$ or $\mathrm{NSE} \leq 0.50$, respectively, and where PBIAS $< \pm 10 \%, \pm 10 \%$ $\leq \mathrm{PBIAS}< \pm 15 \%, \pm 15 \% \leq \mathrm{PBIAS}< \pm 25 \%$ or $\mathrm{PBIAS} \geq$ $\pm 25 \%$, respectively.

\subsection{Bias correction of the GCM data}

The daily outputs of the CMIP5 GCMs from 1948-2100 were spatially interpolated from original resolutions (specified in Table 2 ) to $0.5^{\circ} \times 0.5^{\circ}$ using a bilinear interpolation. The bilinear interpolation is preferred to a simple re-gridding method because it provides a realistic spatial gradient rather than patches of the same meteorological values from a GCM gridcell in multiple $0.5^{\circ}$ gridcells (Koirala and others, 2014). Evaluation of the CMIP5 GCMs over the TP suggested that most reasonably capture the climatological patterns and spatial variations of the observed temperature and that half of the GCMs are able to reproduce the observed seasonal pattern for precipitation (Su and others, 2013), but the GCM outputs contain biases that must be corrected prior to use at the local glacier scale. The delta change approach (e.g. Hay and others, 2000; Graham and others, 2007; Sperna Weiland and others, 2010) is therefore used for bias correction of the GCM data. The approach involves adjusting the GCM daily meteorological variables by adding the difference (temperature) or ratio (precipitation) in 18 year (1988-2005) average monthly means between the GAEORS time series and the GCM time series to obtain daily 

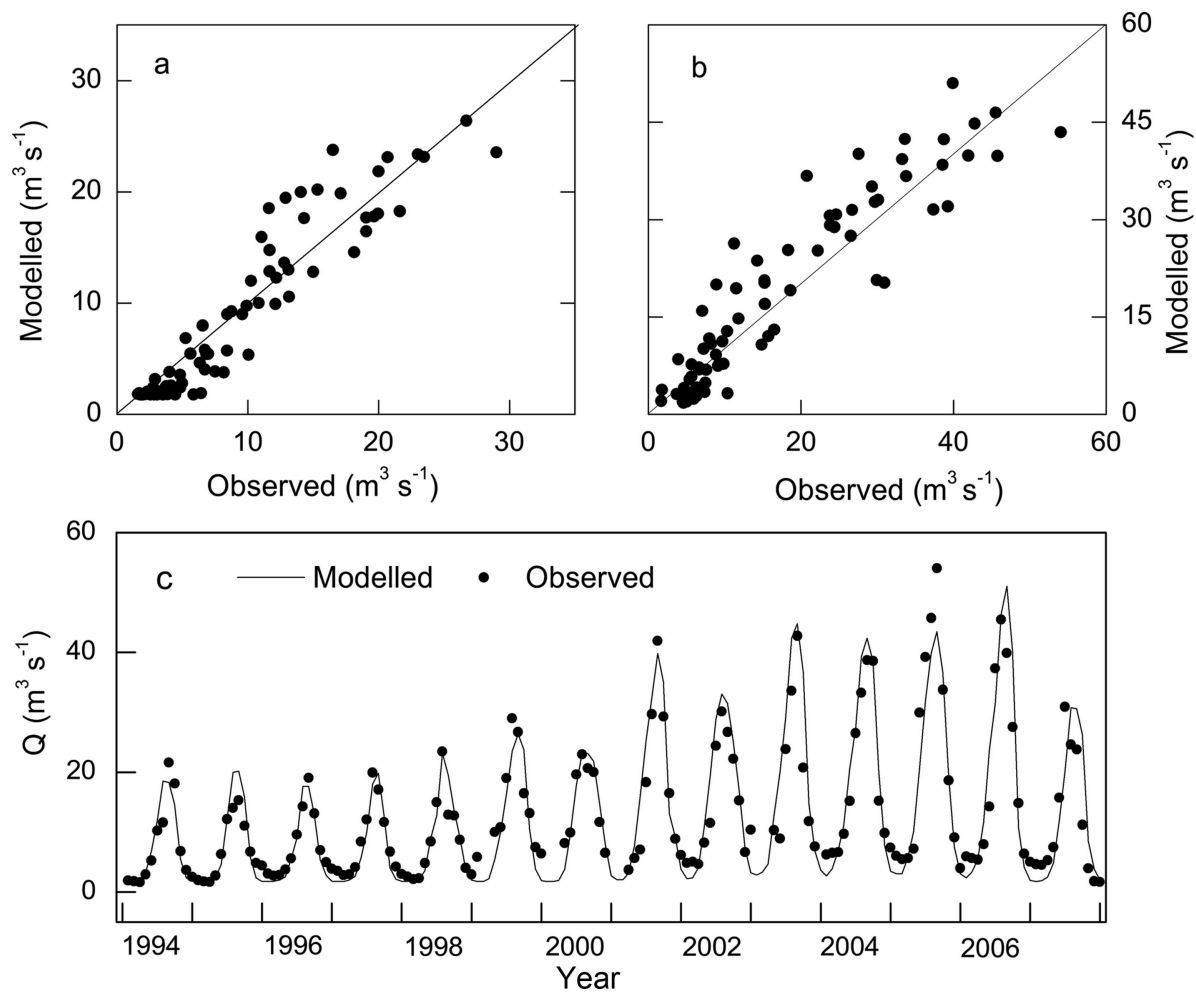

Fig. 3. Scatter diagrams of observed versus modelled monthly runoff $(Q)$ for calibration (a) and validation (b), and time series of observed and modelled monthly runoff for the entire period 1994-2007 (c).

meteorological variables at the gridpoint of the GCMs closest to GAEORS. For temperature and precipitation, an additive correction and a multiplicative correction are used, respectively, as

$$
T_{\text {corrected }}=T_{\mathrm{GCM}}+\left(\bar{T}_{\mathrm{OBS}}-\bar{T}_{\mathrm{GCM}}\right)
$$

and

$$
P_{\text {corrected }}=P_{\mathrm{GCM}} \times\left(\bar{P}_{\mathrm{OBS}} / \bar{P}_{\mathrm{GCM}}\right),
$$

where $T$ and $P$ are the daily temperature and precipitation, $\bar{T}$ and $\bar{P}$ are the 18 year average monthly temperature and precipitation, and subscripts 'OBS', 'GCM' and 'corrected' denote observed, GCM and bias-corrected data. Applying the method as indicated in Eqn (12) results in unrealistic precipitation peaks in the bias-corrected precipitation time series due to large differences between the bias-corrected precipitation amount and the observed amount and number of wet days (Van Beek, 2008; Sperna Weiland and others, 2010). To overcome this limitation, a threshold ( $\left.\bar{P}_{\mathrm{OBS}} / \bar{W}_{\mathrm{OBS}}\right)$ (e.g. Van Beek, 2008; Sperna Weiland and others, 2010), defined as the mean daily precipitation amount observed from GAEORS, is used. If the threshold is not exceeded for the monthly precipitation sum of the GCM or the multiplicative correction factor, the days on which precipitation occurs are calculated from a temperature limit below which a day becomes wet. Here the temperature limit $\left(T_{\text {crit }}\right)$ is calculated as

$$
T_{\text {crit }}=T_{\min \mathrm{GCM}}+\left(T_{\max \mathrm{GCM}}-T_{\min \mathrm{GCM}}\right) \frac{\bar{W}_{\mathrm{OBS}}}{N},
$$

where $T_{\max }$ and $T_{\min }$ are the maximum and minimum temperature of the given month, $\bar{W}_{\mathrm{OBS}}$ is the 18 year average number of wet days for the specific month, and $N$ is the total number of days in the specific month. Consequently, the number of wet days of the GCM per month $\left(W_{\mathrm{GCM}}\right)$ is estimated, and the corresponding precipitation amount for these days ( $P_{\text {corrected_w }}$ ) is calculated as

$$
P_{\text {corrected_w }}=\bar{P}_{\mathrm{OBS}} / W_{\mathrm{GCM}} \text {. }
$$

\section{RESULTS AND DISCUSSION}

\subsection{Model performance}

The surface energy-/mass-balance model used in this study has been tested for its predictive capability for accurate simulation of prognostic variables (e.g. ablation, accumulation and refreezing) at the catchment scale, and in particular has demonstrated its ability to reasonably reproduce ice melt rates beneath various thicknesses of debris observed in different periods (Zhang and others, 2012). The integrated model performance for simulating runoff is assessed by comparing simulated with observed monthly runoff for both calibration (1994-2000) and validation (2001-07) time periods. Scatter plots of simulated versus observed monthly runoff are shown in Figure 3a and $b$, and time series of simulated and observed monthly runoff are presented for the entire period of analysis in Figure 3c. The results of model calibration demonstrate a close agreement between simulated and observed monthly runoff (Fig. 3a and c), yielding an NSE value of 0.86 and PBIAS value of $5 \%$ (Table 3 ). This implies that the model successfully replicates all key glacio-hydrological processes in the catchment using the optimal parameter sets (Table 1), with a rating of 'very good' on the scale of Moriasi and others (2007). Therefore, these parameters are selected as the best solution for further analysis, and the calibrated model is verified against an independent set of runoff data. Although the model yields a lower NSE value (Table 3) for the evaluation period relative to the calibration period, with a PBIAS value of $-7 \%$, the calibrated model generally reproduces the observed runoff well and captures the long- 
Table 3. Model calibration and validation results for the HLG catchment

\begin{tabular}{lcc}
\hline & NSE & PBIAS \\
& & $\%$ \\
\hline Calibration (1994-2000) & & 5.0 \\
Validation (2001-07) & 0.86 & -7.0 \\
Overall (1994-2007) & 0.83 & -4.5 \\
Global gridded data (1994-2007) & 0.85 & -7.0 \\
GCM data (1994-2005) & 0.85 & 12.0 \\
& 0.82 & \\
\hline
\end{tabular}

term trend (Fig. 3c). Note that the calibrated model overestimates the peak summer runoff in most years (Fig. 3c), and overestimates the July-August runoff by an average of $8 \%$. This overestimation may be associated with the glacier extent used in the simulation. The simulation is performed using constant glacier extent during a massbalance year, and the glacier extent used is estimated at the end of the previous mass-balance year. In effect, glacier extent change is a dynamic process in the mass-balance year. Specifically, glacier extent during July-August may be minimum in the mass-balance year due to dramatic melting. Consequently, the simulation with the model-estimated glacier extent overestimates the summer runoff compared to the observed runoff originated from the actual ice extent.

To validate the bias-corrected temperature and precipitation of the GCM and the observation-based global gridded datasets, we calculate the runoff of the catchment using the calibrated model forced by the two datasets. A comparison of simulated and observed monthly runoff for the entire analysis period (Fig. 4a) indicates that the observed runoff is reasonably reproduced by the model forced by the biascorrected datasets. The NSE values for the bias-corrected GCM and global gridded datasets are 0.82 and 0.85 , respectively, and the PBIAS values are $<12 \%$ (Table 3 ). Overall, the bias-corrected temperature and precipitation of the GCM and the observation-based global gridded datasets can be used as input to reproduce river runoff in the catchment well. Additionally, the glacier areas in 1966, 1975, 1994 and 2007 are simulated using the calibrated model forced by the bias-corrected global gridded temperature and precipitation over the period 1951-2007. We then compare the modelled glacier area to satellite-based observations in 1966, 1975, 1994 and 2007/09 derived from Liu and others (2010) and Pan and others (2012), who obtained glacier boundaries for different periods from multispectral satellite data and analysed uncertainties. A comparison of the simulated and satellite-based observations during different periods (Fig. 4b) indicates that the approach used in this study provides good results for periods of glacier change and is capable of capturing the feedback between glacier mass balance and changes in glacier hypsometry.

Overall, the integrated model generally reproduces the observations well. This indicates its capability for simulating glacier mass balance and the runoff at the catchment scale well, assuming that the optimal parameters are valid for different time periods. In particular, we evaluate the use of the bias-corrected GCM and global gridded datasets for modelling in the catchment and believe that accurate estimation of catchment river runoff is possible using the model forced by the bias-corrected datasets.
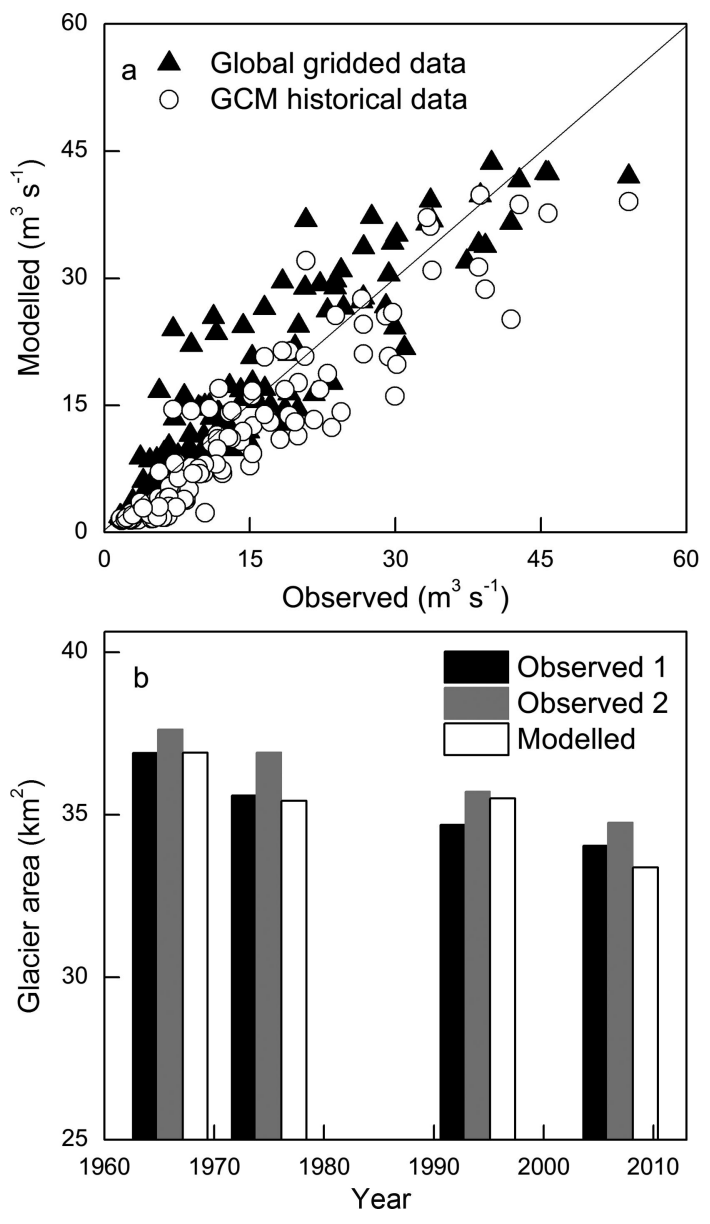

Fig. 4. Scatter diagrams of observed versus simulated monthly runoff calculated from the bias-corrected global gridded climate dataset (1994-2007) and GCM historical data (1994-2005) (a), and satellite-based observed and simulated glacier area in 1966, 1975, 1994 and 2007 (b). Observed 1 and 2 denote satellite-based observed glacier area in different periods obtained from Liu and others (2010) and Pan and others (2012), respectively.

\subsection{Past trend in glacier runoff and its hydrological impacts}

We calculate variations in runoff and its components in the HLG catchment using observed meteorological data (19912013) extended with observation-based global gridded data (1952-90). In the HLG catchment, river runoff is dominated by glacier runoff, which contributes $\sim 53.4 \%$ of total runoff during 1952-2013. Irrespective of glacier runoff, base flow contributes $\sim 22.8 \%$ of total runoff, rainfall runoff is $\sim 16.8 \%$ and snowmelt is $\sim 7 \%$. A consistent trend in glacier runoff and river runoff is observed (Fig. 5c): the runoff shows a slight downward trend over the period 1952-90 but displays a significant upward trend over the period 1991-2013. During 1952-90, decreased temperature is observed (Fig. 5b), particularly in the 1980s, when the catchment is coldest, leading to a small negative mass balance (Zhang and others, 2012). Despite the slight increase in precipitation during this period (Fig. 5a), rainfall runoff and base flow are relatively stable, contributing $38.3 \%$ of total runoff. As a result of the decrease in temperature and limited change in precipitation, glacier runoff is reduced slightly, which is the main cause of the decreased total runoff during 1952-90. On the other hand, air temperature increases significantly (Fig. 5b) at a rate of $0.27^{\circ} \mathrm{C}(10 \mathrm{a})^{-1}$ since 1991 


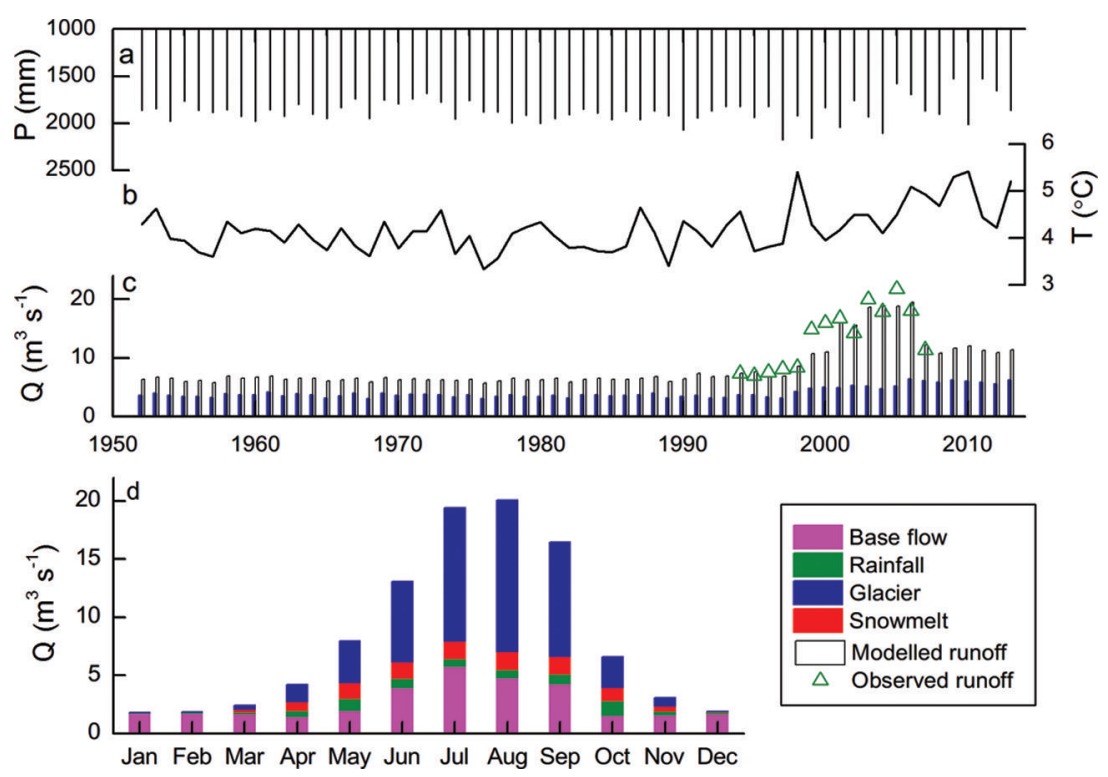

Fig. 5. Variations (1952-2013) in annual precipitation $(P ; \mathrm{a})$, temperature $(T ; \mathrm{b})$ and runoff $(Q ; \mathrm{c})$ in the HLG catchment, and monthly variation in each of the components of total runoff $(\mathrm{d})$. The precipitation and temperature data are derived from the bias-corrected gridded dataset (1952-90) and observed dataset from GAEORS (1991-2013).

(Zhang and others, 2012), while the precipitation initially increases and then decreases slightly (Fig. 5b). During this period, the glaciers of the catchment show significant retreat (Liu and others, 2010) and large negative mass balance (Zhang and others, 2012), with accelerated thinning at a rate of $-1.61 \pm 0.6 \mathrm{~m} \mathrm{a}^{-1}$ (Zhang and others, 2010). As a result of accelerated glacier wasting in the catchment, glacier runoff greatly increases (Fig. 5c). We also observe a consistent increase in runoff from the glacier-free zone. River runoff in the catchment increases by 83\% during 1991-2013 compared with 1952-90. According to our estimation, one-third of the increased total runoff is derived from increased glacier runoff, and the rest comes from other runoff components. In particular, $\sim 47 \%$ of the increased total runoff is attributable to increased glacier runoff during the past 5 years (2009-13).

Monthly variation in the magnitude of the contribution of each runoff component to the total runoff and its intraannual distribution are presented for the period 1961-2013 in Figure $5 \mathrm{~d}$. About $94.5 \%$ of the mean annual glacier runoff is observed between May and October (Fig. 5d), and the peak occurs in August, consistent with river runoff. Runoff is low during the winter months (November-April) due to reduced precipitation, which is predominantly stored as snow. The fraction of glacier runoff approaches zero during the winter months, and runoff from the glacier-free zone of the catchment is a larger component of total runoff (> 64.5\%). With increasing temperature, the contribution from snowmelt reaches a maximum in April $(\sim 18 \%)$ and is also significant at the end of the melt season (Fig. $5 \mathrm{~d}$ ). The contribution from glacier runoff begins to increase and reaches a maximum in August $(\sim 65 \%)$ and is also significant during the other summer months ( 40.2-60\%) (Fig. $5 \mathrm{~d}$ ). The adjacent catchments of our study site on Gongga mountain are within the monsoon-dominated rainfall regime (Cheng and others, 2004), in which the runoff peak occurs in July and is directly related to the peak in rainfall during the summer months. Despite the bulk of precipitation occurring during the summer months, glacier runoff strongly modifies the seasonal distribution of river runoff in the HLG catchment, in contrast to the adjacent catchments where river runoff varies with seasonal variations in rainfall.

As discussed above, the runoff from the HLG catchment has been dominated by glacier runoff during the past 62 years. The trend in glacier runoff, which is principally dependent on the nature of the glacier response to ongoing climate warming, is a significant control on total runoff during periods of lower catchment discharge and intensifies the upward trend of the runoff during periods of higher discharge.

\subsection{Future trend in glacier runoff and its contribution to river runoff}

A consistent and robust feature across GCMs is a continuation of global warming in the 21 st century for all the RCP scenarios (Collins and others, 2013). In the HLG catchment, the temperature projections for RCP4.5 and RCP8.5 reveal a significant warming by 2100 (Fig. $6 a$ and b). The multimodel mean temperature by 2100 is projected to increase at a rate of $0.02^{\circ} \mathrm{Ca}^{-1}$ for RCP4.5 (Fig. 6a) and $0.05^{\circ} \mathrm{Ca}^{-1}$ for RCP8.5 (Fig. 6b) relative to the observed period (19882005). The precipitation projections indicate large variability among the ten GCMs (Fig. 6c and d). On average, an upward trend in precipitation by 2100 is projected at a rate of $1.9 \mathrm{~mm} \mathrm{a}^{-1}$ for RCP4.5 (Fig. 6c) and $3.0 \mathrm{~mm} \mathrm{a}^{-1}$ for RCP8.5 (Fig. 6d) relative to the observed period. Relative to the observed period (1988-2005), temperature is projected to increase by $2.1^{\circ} \mathrm{C}$ for RCP 4.5 and by $4.0^{\circ} \mathrm{C}$ for RCP 8.5 during the period 2071-2100, with projected precipitation increasing by $3 \%$ for RCP 4.5 and by $7 \%$ for RCP 8.5 .

In the HLG catchment, where glacier runoff contributes significantly to total runoff, future evolution of the glacier area is crucial. As a result of increasing temperature, the ensemble of projections for the ten GCMs under RCP4.5 and RCP8.5 shows substantial glacier shrinkage in the HLG catchment (Fig. 6e and f) despite an increase in the projected precipitation (Fig. $6 \mathrm{c}$ and d). There are significant differences in projected glacier area between RCP4.5 and 

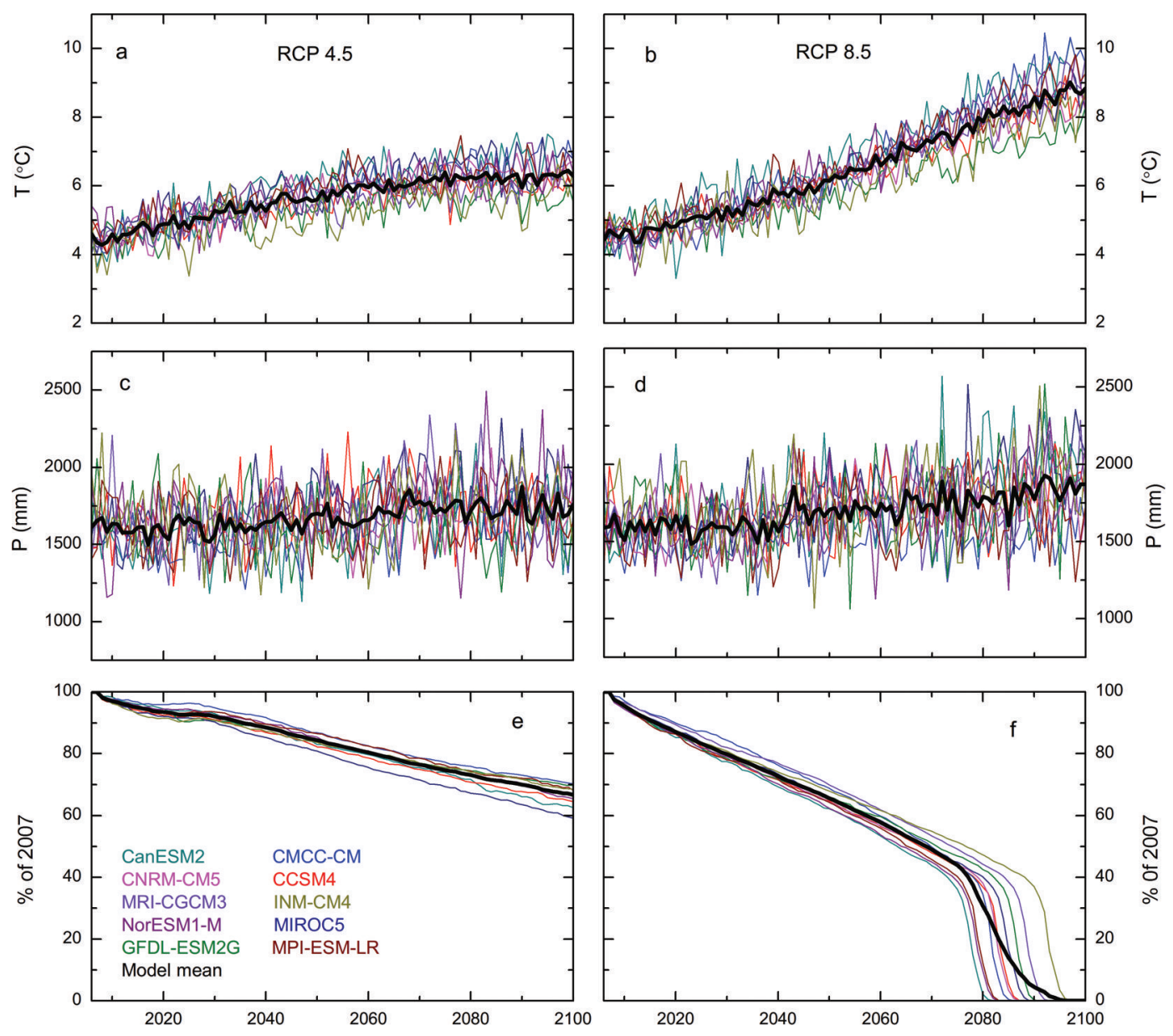

Fig. 6. Projections of annual mean temperature and annual precipitation from ten GCMs, and projected anomalies in glacier area relative to the 2007 area based on two scenarios (RCP4.5 left side, RCP8.5 right side). Black curve in each plot is the mean of the ensemble.

RCP8.5, and the discrepancy between the RCP scenarios is considerably larger in the second half of the 21 st century. A steady decline in glacier area in the catchment is projected for RCP4.5 (Fig. 6e), whereas a rapid decline is projected for RCP8.5 (Fig. 6f). Relative to the 2007 glacier area, the glacier area of the catchment is projected to decrease by $15.6 \%$ for RCP 4.5 and by $34.4 \%$ for RCP 8.5 by 2050 , whereas the reduction is $24 \%$ and $51 \%$, respectively, by 2070. After 2070, glacier shrinkage is remarkably accelerated for RCP8.5 due to more ice melting and less snow accumulation (Fig. 7). Relative to 1994-2013, ice melting in the high-altitude zone is projected to increase by $30 \%$ in $2021-50$ and by 59\% in 2071-2100 for RCP4.5 and by 35\% in 2021-50 and $122 \%$ in 2071-2100 for RCP8.5 (Fig. 7). Particularly enhanced melting occurs in the entire highaltitude zone in 2071-2100 for RCP8.5 owing to the remarkable increase in temperature (Fig. 6a and b). Snow accumulation in the high-altitude zone is projected to decrease for both RCPs as the increasing temperature and limited change in precipitation result in a shift toward more liquid precipitation (Fig. 7). Snow accumulation does not change much under RCP4.5, with only a $4.6 \%$ decrease during both 2021-50 and 2071-2100 relative to 19942013 , whereas it decreases by $5 \%$ in $2021-50$ and by $12 \%$ in 2071-2100 for RCP8.5.

The multi-model means of projected variations in runoff for RCP4.5 and RCP8.5 are presented in Figure 8. River runoff of the catchment is projected to decrease initially for both RCPs and then to display opposite trends under the two scenarios in the following decades, with the spread between the scenarios increasing in the second half of this century. Under both RCPs, multi-model mean glacier runoff shows different trends in the catchment (Fig. 8a). Glacier runoff remains relatively stable under the RCP4.5 scenario, because enhanced meltwater as a result of temperature can compensate for the steady reduction in glacier storage with glacier shrinkage. The contribution of glacier runoff to total runoff does not change much, varying from $\sim 39.5 \%$ in $2021-50$ to $33.4 \%$ in $2071-2100$. Other runoff components generated from the glacier-free zone show a slight increase owing to an increase in precipitation and a decrease in glacierized area (Fig. 6). Thus, the total runoff of the catchment increases slightly toward the end of this century for RCP4.5 (Fig. 8a). Although the contribution of glacier runoff to total runoff, $\sim 37.2 \%$ during 2011-2100 for RCP4.5, decreases slightly compared with the previous contribution, glacier runoff is still an important component of total runoff until 2100. Compared to the RCP4.5 scenario, the projected temperature shows larger increase under the RCP8.5 scenario. In particular, temperature rise becomes relatively stable for RCP4.5 in the second half of this century, whereas temperature experiences significant increase for RCP8.5 (Fig. 6a and b). In responding to temperature rise, more ice meltwater is released from glacier storage under the RCP8.5 scenario, and glacier area, especially in high-altitude regions, decreases significantly, representing $\sim 17 \%$ of that under the RCP4.5 in 2100 (Fig. 2). Although glacier runoff is slightly enhanced before 

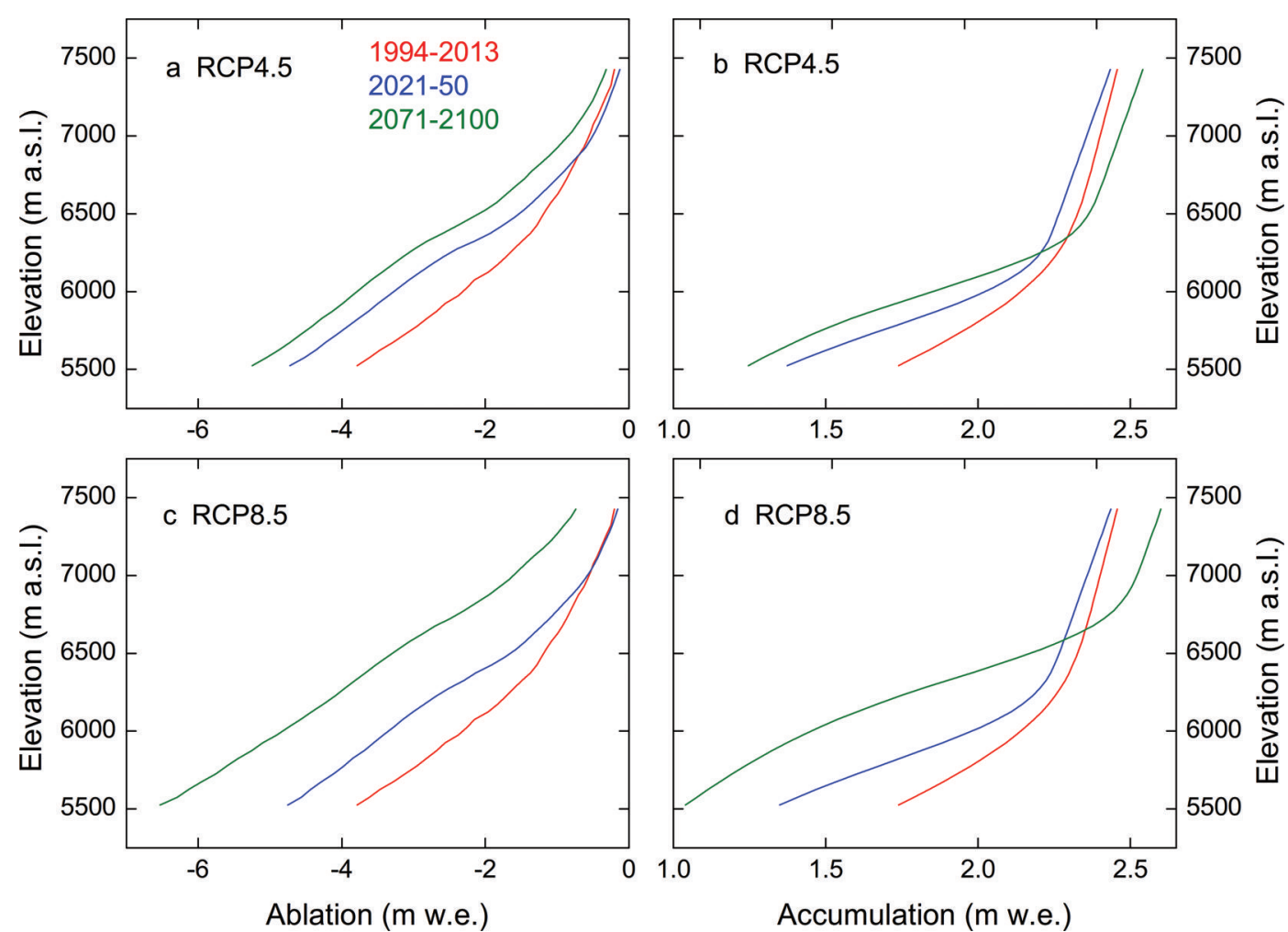

Fig. 7. Projections of ablation (a, c) and snow accumulation (b, d) in the high-altitude zone for the periods 1994-2013, 2021-50 and 2071-2100 for RCP4.5 (a, b) and RCP8.5 (c, d).

2050 for RCP8.5 compared to that for RCP4.5 (Fig. 8a), with decreasing glacier area, glacier runoff will gradually diminish in the second half of this century as enhanced meltwater cannot compensate for the dramatic reduction in glacier area. Specifically, it may ultimately approach zero due to the remarkable reduction in glacier volume at the end
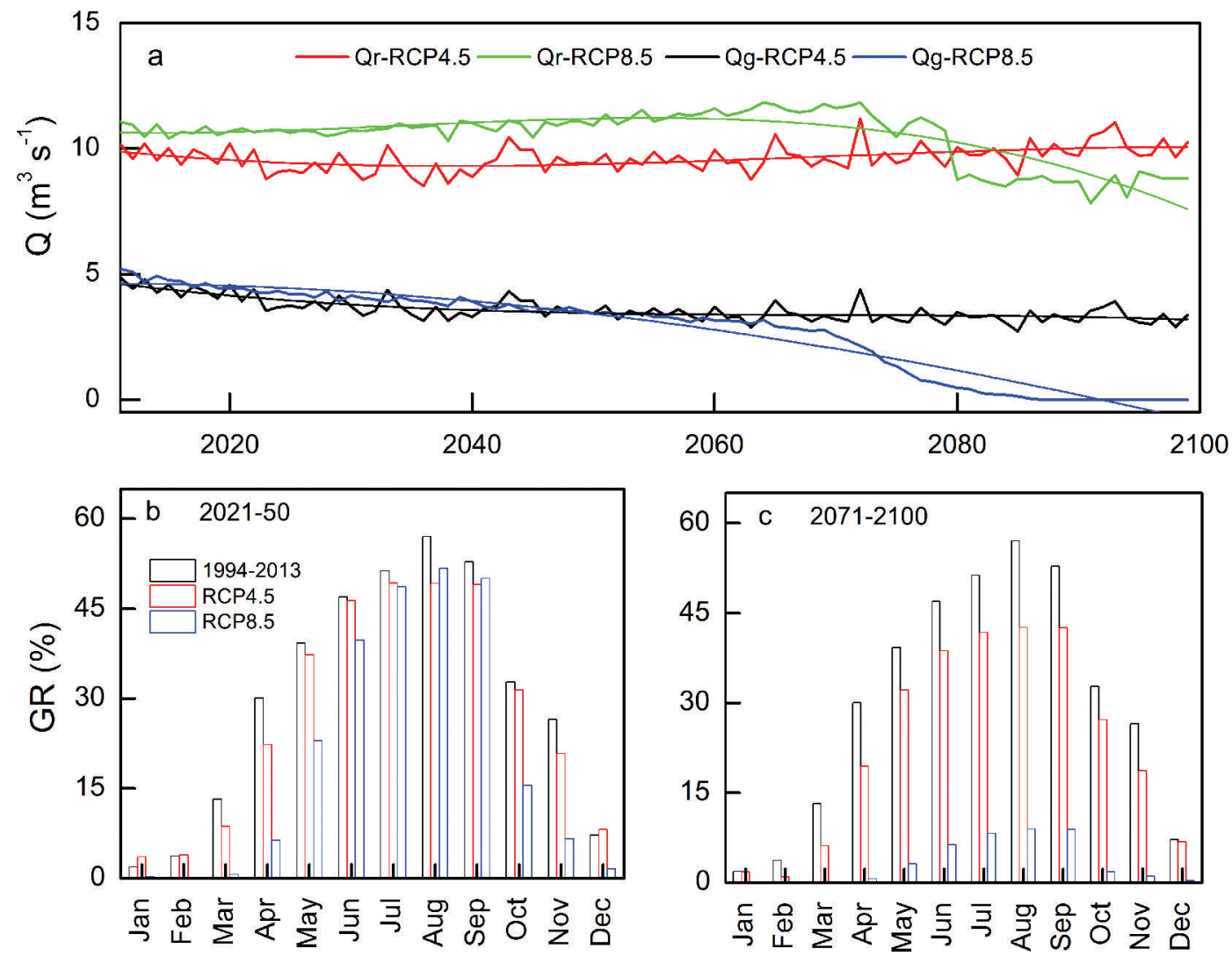

Fig. 8. Future glacier runoff $(\mathrm{Qg})$ and river runoff $(\mathrm{Qr})$ for RCP4.5 and RCP8.5 (a), and monthly contribution of glacier runoff to total runoff (GR; b) in different periods of 1994-2013, 2021-50 and 2071-2100 for RCP4.5 and RCP8.5. 
of this century (Fig. 8a). Despite the significant increase in runoff generated from the glacier-free zone of the catchment for RCP8.5 due to an increase in precipitation and area of the glacier-free zone, the increased amount of water from the glacier-free zone can compensate for only $\sim 60 \%$ of the water deficiency from reduced glacier runoff and thus cannot offset the deficit from the reduced glacier runoff. Consequently, total runoff is projected to decrease for RCP8.5, especially after 2070 (Fig. 8). Under the RCP8.5 scenario, glacier runoff is an important component of the total runoff until 2050, contributing $\sim 36.4 \%$ of the total runoff in 2021-50, but then the contribution decreases and is only $5.2 \%$ in $2071-2100$. Hence, the runoff generated from the glacier-free zone of the catchment gradually becomes the principal contributor to the total runoff of the catchment after 2070 for RCP8.5.

\subsection{Discussion}

\subsubsection{Impact of glacier runoff on the hydrological regime}

The response of glacier runoff to climate warming is a matter of timescale (Jansson and others, 2003), i.e. runoff increases initially due to enhanced melting but then decreases gradually in the long term as a consequence of reduced glacier volume. Hence, glacier runoff will peak at a certain time (Jansson and others, 2003), the timing of which is crucial to the future water supply in the glacier-fed catchments (Radić and Hock, 2011; Immerzeel and others, 2013; Bliss and others, 2014; Lutz and others, 2014). Radić and Hock (2011) estimated the peak around 2075 on the global scale, but significant differences in the timing of the peak are apparent from region to region (Casassa and others, 2009; Immerzeel and others, 2013; Bliss and others, 2014; Lutz and others, 2014). A consistent increase in runoff is expected for five basins in the Himalaya until at least 2050 (Immerzeel and others, 2013; Lutz and others, 2014), whereas Bliss and others (2014) found significant decreases in annual glacier runoff over the 21st century for Central Asia and South Asia East, but no significant changes for South Asia West. For the specific conditions of the HLG catchment, which presently has extensive debris-covered and debris-free ice covering a large area and altitude range, we estimate that the peak of glacier runoff in the catchment occurs in recent years (2006-10; Figs 5 and 8). After the peak, a decrease in glacier runoff is projected in the catchment for both RCPs, but there are large differences between the two scenarios regarding the role of glacier runoff in the catchment.

As discussed above, glacier runoff is a large component of the total runoff in the HLG catchment, and its evolution can change the magnitude and timing of the annual hydrograph, with a seasonal redistribution in total runoff. The present hydrological regime of the catchment is glacierrunoff dominated, and peak flows are driven by glacier runoff. The average contribution of glacier runoff to total runoff is $\sim 53.4 \%$ during 1952-2013, and the monthly contribution during summer months varies from $40.2 \%$ to $65 \%$. The average contribution from glacier runoff for RCP4.5 is $39.5 \%$ in $2021-50$ and becomes $33.4 \%$ in $2071-$ 2100 , and the monthly contribution during summer months varies from $31.4 \%$ to $49.4 \%$ in $2021-50$ and from $27.2 \%$ to $42.6 \%$ in 2071-2100 (Fig. 8). Glacier runoff still affects the variation in total runoff, but the contribution from glacier runoff decreases slightly. This implies that the hydrological regime of the catchment will transform from a glacialpluvial type to a pluvial type by the end of this century. Compared with the RCP4.5 scenario, a similar contribution of glacier runoff to total runoff is projected for RCP8.5 until 2050 (Fig. 8b), but the amount of glacier runoff for RCP8.5 is larger (Fig. 8a). The average contribution of glacier runoff to total runoff for RCP8.5 decreases from $36.4 \%$ in $2021-50$ to $5.2 \%$ in 2071-2100, and the monthly contribution during summer months varies from $15.5 \%$ to $51.8 \%$ in $2021-50$ and from $1.8 \%$ to $9 \%$ in $2071-2100$ (Fig. $8 b$ and c). The contribution from glacier runoff may approach zero by the end of this century due to the disappearance of glaciers (Fig. 6f), and runoff generated from the glacier-free zone is expected to be the main contributor to total runoff. This implies that the hydrological regime of the catchment under the RCP8.5 scenario will be a completely pluvial type by the end of this century. Runoff from the glacier-free zone increases significantly under both scenarios by the end of the century, but the increase under the RCP8.5 scenario cannot compensate for the water deficiency from the reduction in glacier runoff. Thus, the total runoff decreases slightly for RCP8.5, whereas it increases slightly for RCP4.5. These results clearly indicate the vital role of glaciers and their runoff in the runoff variations and hydrological regime of the HLG catchment.

\subsubsection{Effect of debris cover}

The HLG catchment is dominated by debris-covered glaciers, which cover $\sim 34.8 \mathrm{~km}^{2}$. The total debris-covered area represents $\sim 39 \%$ of the total area of the ablation zones of the three debris-covered glaciers (Zhang and others, 2012). As previous studies have reported (Østrem, 1959; Nakawo and Young, 1981; Mattson and others, 1993), dispersed and thin debris enhances ice melt rates through albedo reduction, whereas debris cover of thickness exceeding a few centimetres reduces ice melt by imposing a barrier between the ice and the atmosphere. In situ surveys of debris thickness in the HLG catchment indicate its inhomogeneous distribution in space, and the thickness varies from several millimetres in the upper part of the ablation zone to $>1.0 \mathrm{~m}$ at the terminus (Zhang and others, 2011 ). Of the surveyed area, $\sim 50.3 \%$ has a debris thickness $<0.1 \mathrm{~m}$ and $\sim 25 \%$ has a thickness $<0.03 \mathrm{~m}$. Due to the inhomogeneous distribution of debris thickness, $\sim 67 \%$ of the ablation area on HLG glacier, the largest glacier in the catchment (Fig. 1), has undergone accelerated melting, whereas $\sim 19 \%$ of the ablation area has experienced inhibited melting, and the sub-debris melt rate equals the bare-ice melt in only $14 \%$ of the ablation area (Zhang and others, 2011, 2012). Therefore, the accelerating effect of debris cover dominates in the catchment so that ice melt rates are higher compared to clean ice, which significantly affects glacier runoff by altering spatial patterns of ice melting, with important consequences for total runoff of the HLG catchment. To comprehensively assess the influence of debris cover on the total runoff of the catchment, we recalculate the runoff with an assumption of no debris cover on the three debris-covered glaciers. Compared with the nodebris assumption case, the mean annual glacier runoff increases by $\sim 22 \%$ under the plausible real surface condition during 1991-2013. As a consequence, the catchment runoff increases by $\sim 8.1 \%$ during this period. Based on this comparison, we argue that the debris-covered area on the three glaciers can supply significant excess 


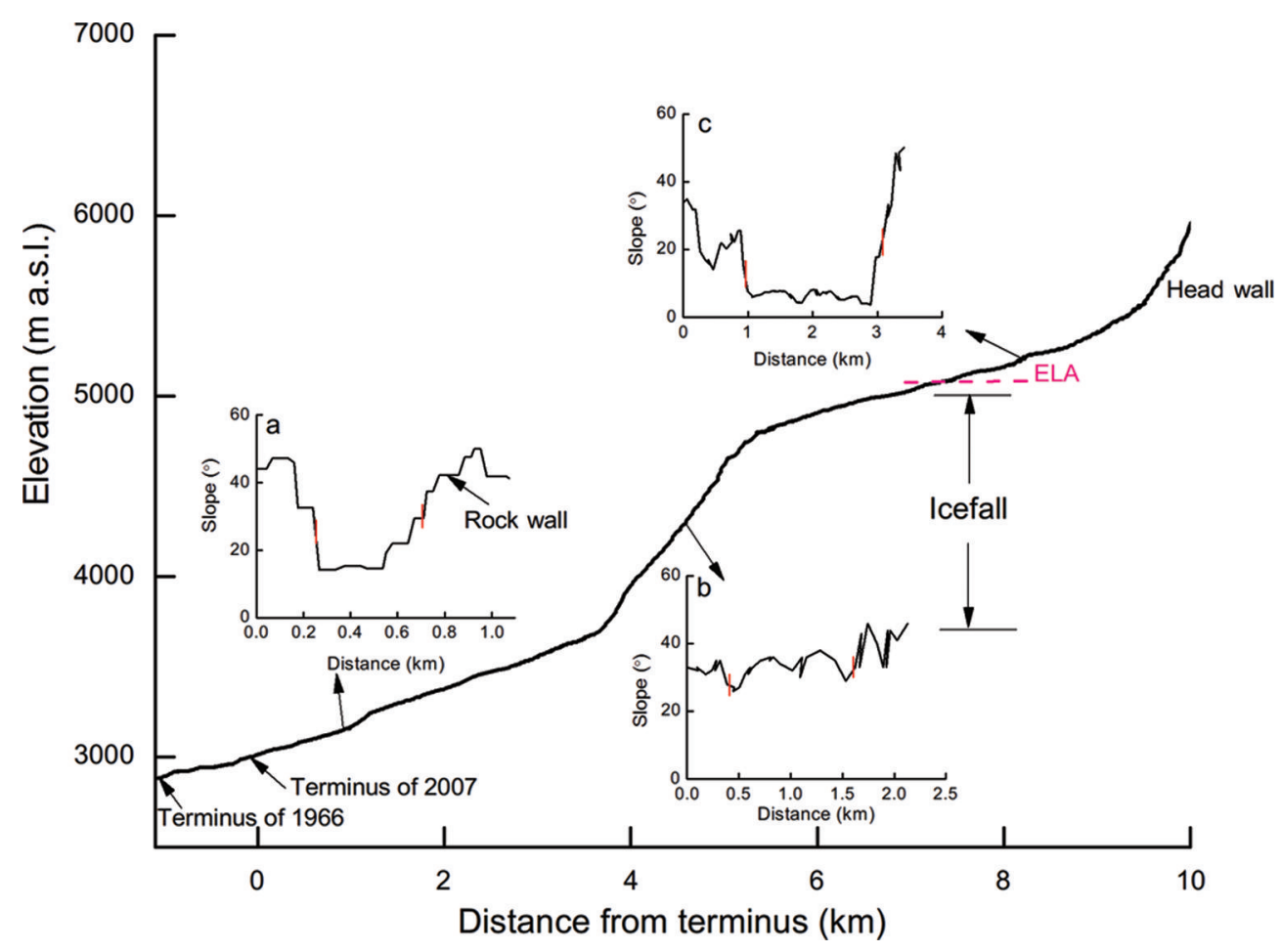

Fig. 9. Schematic of topography and ice surface in the HLG catchment. Glacier surface elevation is derived from the DEM. Short red line segments denote glacier boundaries. Distance in $(\mathrm{a}-\mathrm{c})$ denotes the distance from the western to the eastern side.

meltwater to the total runoff in the catchment. This finding is similar to that estimated for Trambau Glacier, Nepal Himalaya (Fujita and Sakai, 2014). Both sites are characterized by thinner debris cover in the ablation zones.

In the HLG catchment, most of the debris cover occurs below 5000 ma.s.l. (Figs 1 and 2), where a nearly $1300 \mathrm{~m}$ high icefall exists from 3700 to $4980 \mathrm{~m}$ a.s.l. (Figs 1 and 9) and the slope of surrounding rock walls is steep (Fig. 9). The topographic settings mainly control the formation conditions of debris-covered surface in the catchment, because the debris of the three glaciers is derived mainly from mixed ice/ snow/rock avalanching from the icefall and surrounding rock walls through frost-weathering processes and structural rockfalls (Li and Su, 1996). Scherler and others (2011) suggested that the fraction of a glacier surface covered with supraglacial debris is related to the steepness of the ice-free zone above the snowline, based on the hypothesis that steeper ice-free areas tend to cause avalanches and therefore supply more debris to the glacier. Although the ice-free zone in the accumulation zone is steep, the icefall prevents the formation of debris-covered surface in the zone above the icefall (Fig. 9). In recent decades, glacier termini in the HLG catchment have retreated significantly ( $\mathrm{Su}$ and others, 1992; Liu and others, 2010; Pan and others, 2012). For example, the termini of Glacier No. 2 and HLG glacier retreated by $\sim 1100 \mathrm{~m}$ during the period 1930-90 (Su and others, 1992) and by $\sim 1878 \mathrm{~m}$ during the period 19302007 (Su and others, 1992; Liu and others, 2007). However, the proportion of debris-covered surface area does not increase as the glaciers recede in the catchment. Specifically, there is no formation of debris-covered surface in the zone above the icefall. This phenomenon is observed by in situ surveys on HLG glacier during different periods (Su and others, 1992; Li and Su, 1996; Zhang and others, 2011), and is also estimated by our model under both RCP scenarios. Despite some shortcomings (discussed below), we use volume-area and volume-length scaling in our model to capture the feedback between glacier mass balance and changing glacier hypsometry. In particular, the evolution of the debris-covered area with decreasing glacier area is taken into account in the projections under the two RCP scenarios using a prescribed debris-covered proportion at each elevation band from satellite estimates. For both RCPs, glacier termini of the catchment are projected to shift upslope as glaciers shrink (Fig. 6e and f). The specific topographic conditions of the catchment may prevent the formation of a debris-covered surface in the ablation zone, leading to a decrease in area of debriscovered surface with glacier termini shifting upslope. As a result, the debris-cover effect will diminish gradually for both RCPs. To assess the influence of debris cover on the total runoff of the catchment for both RCPs, we recalculate the runoff assuming that there is no debris cover on the estimated debris-covered area in the catchment. A comparison of the simulations with the plausible real surface condition and the no-debris assumption case reveals that the effect of debris cover is not apparent under both RCP scenarios due to decreasing debris-covered area. However, when the termini of the three glaciers are projected to shift above the icefall for both RCPs (Fig. 2), our model does not consider the evolution of the debris-covered area above $5000 \mathrm{~m}$ a.s.l. for both RCPs. Hence, the future debris-cover effect on total runoff may be underestimated for both RCPs.

\subsubsection{Model uncertainties}

To calculate the downward shortwave radiation in our simulation, we use a favourable correlation between precipitation and atmospheric transmissivity of solar radiation to estimate the transmissivity. This relationship was established by Zhang and others (2012) in the HLG catchment. Similar relationships have been found on different glaciers of the TP and performed well (e.g. Matsuda and 
others, 2006; Sakai and others, 2009). Zhang and others (2012) suggested that shortwave radiation fluctuations are well simulated using this approach compared to observations in the HLG catchment. To quantify the uncertainty of this approach in the runoff simulation, we recalculate the catchment runoff using the model forced by the estimated shortwave radiation for the period 2005-13, during which the observed shortwave radiation data are available in the catchment. As shown in Figure 10a, the observed runoff during 2005-07 is reasonably reproduced by the model forced by the observed and estimated shortwave radiation datasets, respectively. The NSE values for the two datasets are 0.86 , and the PBIAS values are $<7 \%$. A comparison of the simulations forced by the observed and estimated shortwave radiations reveals a difference of $\sim 5 \%$ in the total catchment runoff and $\sim 10 \%$ in the July-August runoff during 2005-13 (Fig. 10b). The relationship is established based on monthly data, for which low-transmissivity data with high precipitation may not be taken into account, leading to an overestimate of the shortwave radiation on some days, which results in overestimation of the catchment runoff. Based on this comparison, we argue that the resulting uncertainty has a slight effect on the runoff estimate in the catchment (Fig. 10).

In addition to uncertainties in the simulation of future monsoon precipitation in the current GCMs (Kripalani and others, 2007; Immerzeel and others, 2013; Su and others, 2013), our calculation contains several other potential uncertainties. As previous studies have shown (Cheng and others, 2004; Liu and others, 2010; Zhang and others, 2012), evaporation currently has little influence on the water balance of the HLG catchment. However, water loss from evaporation is likely to increase and become considerable toward the end of this century owing to a decrease in glacierized area and a corresponding increase in the glacier-free zone. Although our projection of evaporation considers the increase in area of the glacier-free zone, the effects of changing surface types with an increased area of vegetation are not taken into account. Additionally, the evolution of glacier area is simulated using a volume-area scale, which is a preliminary approximation with known shortcomings (Lüthi, 2009). This process requires a physically based ice-dynamic model, but this remains challenging due to a lack of input data (e.g. ice thickness and velocity). Although the volume-area scale has some shortcomings (Lüthi, 2009), it can reasonably capture the feedback between glacier mass balance and changes in glacier hypsometry (Radić and others, 2008; Marzeion and others, 2012; Hirabayashi and others, 2013), which is important for a catchment in which few input data related to ice-dynamic processes are available.

\section{CONCLUSIONS}

The presented approach includes all major glacio-hydrological processes in a highly glacierized catchment, the HLG catchment, and especially accounts for the spatial characteristic of debris cover and its influence on the melting rate of the underlying ice. It offers the possibility to analyse the magnitude of the contribution of each runoff component (glacier runoff, rainfall, snowmelt and base flow) to river runoff under past and future climatic conditions. Past trends in the runoff components of the catchment indicate that glacier runoff has been the principal source of the total
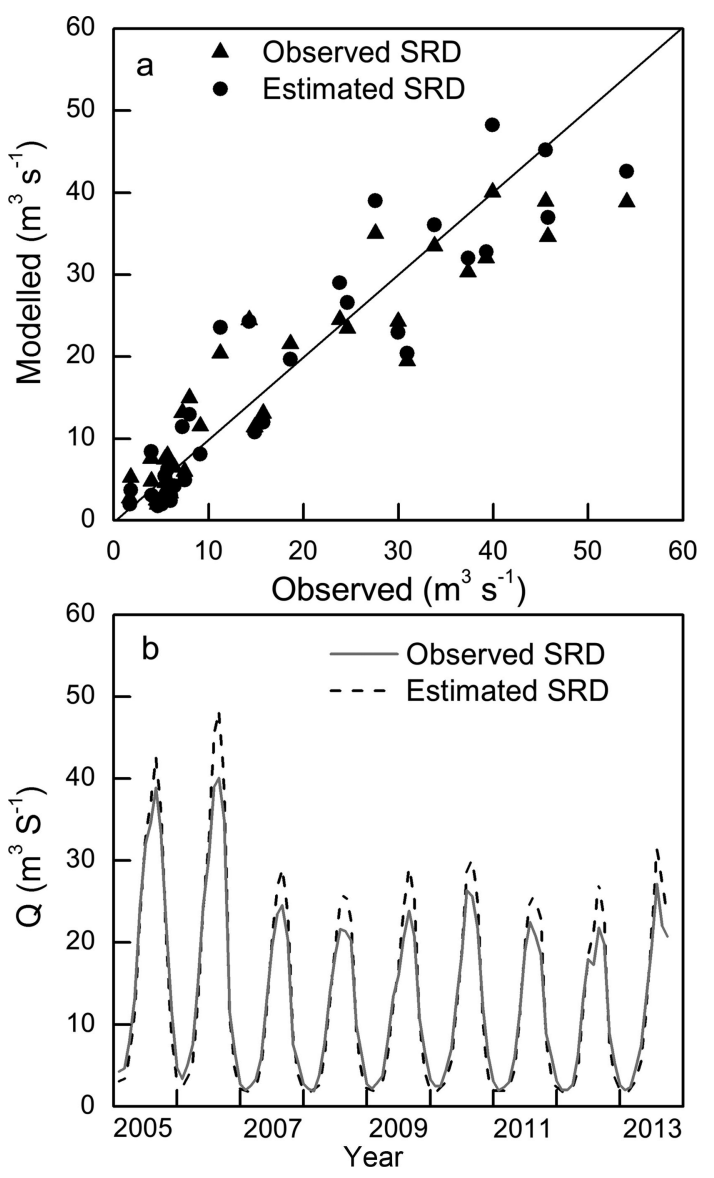

Fig. 10. Scatter plots of observed versus simulated monthly runoff calculated from the observed and estimated shortwave radiation (SRD) datasets during 2005-07 (a) and time series of the simulations forced by the observed and estimated SRD for the period 2005-13 (b).

runoff in the catchment, contributing $53.4 \%$ of the total runoff during 1952-2013. The trend in glacier runoff is a significant control on the total runoff during periods of low river discharge and strongly intensifies the upward trend of total runoff during periods of high discharge. An experimental analysis in which no debris cover is assumed on the three glaciers in the catchment suggests that excess meltwater from the debris-covered area in the ablation zones of the three glaciers provides an $8.1 \%$ increase in total runoff relative to the no-debris assumption case.

The resulting quantification of the future contribution of glacier runoff to river runoff for RCP4.5 and RCP8.5 suggests that although glacier area will be reduced by the remarkable warming, the role of glacier runoff in the water supply of the catchment shows significant differences between the two RCP scenarios, and the spread between the RCPs increases in the second half of this century, with important consequences for the hydrological regime of the catchment. Under the RCP4.5 scenario, glacier runoff remains relatively stable, followed by a slight decrease, contributing $\sim 37.2 \%$ of the total runoff during 2011-2100, which leads to a slight increase in river runoff toward the end of this century in combination with an increase in the runoff generated from the glacier-free zone. On the other hand, glacier runoff is an important component of total runoff only until 2050 for RCP8.5, contributing $\sim 36.4 \%$ on average of the total runoff in $2021-50$ and $\sim 5.2 \%$ in $2071-2100$, which results in the 
hydrological regime transforming from glacial-pluvial to pluvial type. Such differing variations in total runoff under the two RCP scenarios underline the vital role of glaciers and related runoff in variations in river runoff and the hydrological regime in the catchment.

\section{ACKNOWLEDGEMENTS}

This work was supported by the International Science \& Technology Cooperation Program (2010DFA92720-23), National Science \& Technology Support Program (2012BAC19B07), and the Environment Research and Technology Development Fund (S-14) of the Ministry of the Environment, Japan, and JSPS KAKENHI Grant-in-Aid for Scientific Research (C) No. 15K06228. We thank the Gongga Alpine Ecosystem Observation and Research Station (GAEORS) of the Chinese Ecological Research Network for providing hydro-meteorological data. Two anonymous reviewers helped to improve the paper, as did the comments of the Scientific Editor, David Rippin, who is warmly acknowledged.

\section{REFERENCES}

Allen RG, Pereira LS, Raes D and Smith M (1998) Crop evapotranspiration guidelines for computing crop water requirements. (Irrigation and Drainage Paper No. 56) Food and Agriculture Organization, United Nations, Rome

Bahr DB (1997) Global distributions of glacier properties: a stochastic scaling paradigm. Water Resour. Res., 33, 1669-1679

Bahr DB, Meier MF and Peckham SD (1997) The physical basis of glacier volume-area scaling. J. Geophys. Res., 102(B9), 20355-20362

Baker D, Escher-Vetter $\mathrm{H}$, Moser $\mathrm{H}$, Oerter $\mathrm{H}$ and Reinwarth $\mathrm{O}$ (1982) A glacier discharge model based on results from field studies of energy balance, water storage and flow. IAHS Publ. 138 (Symposium at Exeter - Hydrological Aspects of Alpine and High Mountain Areas), 103-112

Bliss A, Hock R and Radić V (2014) Global response of glacier runoff to twenty-first century climate change. J. Geophys. Res., 119(4), 717-730 (doi: 10.1002/2013jf002931)

Casassa G, López P, Pouyaud B and Escobar F (2009) Detection of changes in glacial run-off in alpine basins: examples from North America, the Alps, central Asia and the Andes. Hydrol. Process., 23(1), 31-41 (doi: 10.1002/hyp.7194)

Cheng G, Yu X and Zhao Y (2004) The hydrological cycle and its mathematical models of forest ecosystem in mountains. Science Press, Beijing [in Chinese]

Collins M and 13 others (2013) Long-term climate change: projections, commitments and irreversibility. In Stocker TF and 9 others eds Climate change 2013: the physical science basis. Contribution of Working Group I to the Fifth Assessment Report of the Intergovernmental Panel on Climate Change. Cambridge University Press, Cambridge and New York

Cruz RV and 9 others (2007) Asia. In Parry ML, Canziani OF, Palutikof JP, Van der Linden PJ and Hanson CE eds Climate change 2007: impacts, adaptation and vulnerability. Cambridge University Press, Cambridge and New York

Escher-Vetter H (2000) Modelling meltwater production with a distributed energy balance method and runoff using a linear reservoir approach: results from Vernagtferner, Oetztal Alps, for the ablation seasons 1992 to 1995. Z. Gletschkd. Glazialgeol., 36, 119-150

Fan Y and Van den Dool HVD (2008) A global monthly land surface air temperature analysis for 1948-present. J. Geophys. Res., 113(D1), D01103 (doi: 10.1029/2007JD008470)
Fujita K (2007) Effect of dust event timing on glacier runoff: sensitivity analysis for a Tibetan glacier. Hydrol. Process., 21(21), 2892-2896 (doi: 10.1002/hyp.6504)

Fujita K (2008) Effect of precipitation seasonality on climatic sensitivity of glacier mass balance. Earth Planet. Sci. Lett., 276, 14-19 (doi: 10.1016/j.epsl.2008.08.028)

Fujita K and Ageta Y (2000) Effect of summer accumulation on glacier mass balance on the Tibetan Plateau revealed by massbalance model. J. Glaciol., 46(153), 244-252

Fujita K and Nuimura T (2011) Spatially heterogeneous wastage of Himalayan glaciers. Proc. Natl Acad. Sci. USA (PNAS), 108(34), 14011-14014 (doi: 10.1073/pnas.1106242108)

Fujita K and Sakai A (2014) Modelling runoff from a Himalayan debris-covered glacier. Hydrol. Earth Syst. Sci., 18(7), 2679-2694 (doi: 10.5194/hess-18-2679-2014)

Gardner AS and 15 others (2013) A reconciled estimate of glacier contributions to sea level rise: 2003 to 2009. Science, 340(6134), 852-857 (doi: 10.1126/science.1234532)

Glover J and McCulloch G (1958) The empirical relation between solar radiation and hours of sunshine. Q. J. R. Meteorol. Soc., 84, 172-175

Graham LP, Andréasson J and Carlsson B (2007) Assessing climate change impacts on hydrology from an ensemble of regional climate models, model scales and linking methods: a case study on the Lule River basin. Climatic Change, 81(S1), 293-307 (doi: 10.1007/s10584-006-9215-2)

Hay JE and Fitzharris BB (1988) The synoptic climatology of ablation on a New Zealand glacier. J. Climatol., 8, 201-205

Hay L, Wilby RL and Leavesley GH (2000) A comparison of delta change and downscaled GCM scenarios for three mountainous basins in the United States. J. Am. Water Res. Assoc., 362, 387-397

Hirabayashi Y, Kanae S, Motoya K, Masuda K and Döll P (2008) A 59-year (1948-2006) global near-surface meteorological data set for land surface models. Part I: Development of daily forcing and assessment of precipitation intensity. Hydrol. Res. Lett., 2, 36-40 (doi: 10.3178/HRL.2.36)

Hirabayashi Y, Döll P and Kanae S (2010) Global-scale modeling of glacier mass balances for water resources assessments: glacier mass changes between 1948 and 2006. J. Hydrol., 390, 245-256 (doi: 10.1016/j.jhydrol.2010.07.001)

Hirabayashi Y, Zhang Y, Watanabe S, Koirala S and Kanae S (2013) Projection of glacier mass changes under a high-emission climate scenario using the global glacier model HYOGA2. Hydrol. Res. Lett., 7(1), 6-11 (doi: 10.3178/hrl.7.6)

Hock R and Jansson P (2005) Modelling glacier hydrology. In Anderson M ed. Encyclopedia of hydrological sciences. John Wiley \& Sons, Ltd, Chichester, 2647-2655

Hock R and Noetzli C (1997) Areal melt and discharge modelling of Storglaciären, Sweden. Ann. Glaciol., 24, 211-216

Immerzeel WW, Van Beek LPH and Bierkens MFP (2010) Climate change will affect the Asian water towers. Science, 328(5984), 1382-1385 (doi: 10.1126/science.1183188)

Immerzeel WW, Pellicciotti F and Bierkens MFP (2013) Rising river flows throughout the twenty-first century in two Himalayan glacierized watersheds. Nature Geosci., 6(9), 742-745 (doi: 10.1038/NGEO1896)

Jansson P, Hock R and Schneider T (2003) The concept of glacier storage: a review. J. Hydrol., 283, 116-129 (doi: 10.1016/ S0022-1694(03)00258-0)

Kaser G, Großhauser M and Marzeion B (2010) Contribution potential of glaciers to water availability in different climate regimes. Proc. Natl Acad. Sci. USA (PNAS), 107(47), 2022320227 (doi: 10.1073/pnas.1008162107)

Koirala S, Hirabayashi Y, Mahendran R and Kanae S (2014) Global assessment of agreement among streamflow projections using CMIP5 model outputs. Environ. Res. Lett., 9(6), 064017 (doi: 10.1088/1748-9326/9/6/064017)

Kondo J (1994) Meteorology of water environment. Asakura, Tokyo [in Japanese] 
Kripalani RH, Kulkarni JHOA, Sabade SS and Chaudhari HS (2007) South Asian summer monsoon precipitation variability: coupled climate simulations and projections under IPCC AR4. Theor. Appl. Climatol., 90(3-4), 133-159 (doi: 10.1007/s00704-0060282-0)

Legates DR and McCabe GJ (1999) Evaluating the use of 'goodnessof-fit' measures in hydrologic and hydroclimatic model validation. Water Resour. Res., 35(1), 233-241 (doi: 10.1029/ 1998wr900018)

Li J and Su Z (1996) Glaciers in the Hengduan Mountains. Science Press, Beijing [in Chinese]

Liu Q and 6 others (2010) Recent shrinkage and hydrological response of Hailuogou glacier, a monsoon temperate glacier on the east slope of Mount Gongga, China. J. Glaciol., 56(196), 215-224 (doi: 10.3189/002214310791968520)

Liu S, Zhang Y, Zhang Y and Ding Y (2009) Estimation of glacier runoff and future trends in the Yangtze River source region, China. J. Glaciol., 55(190), 353-362 (doi: 10.3189/ 002214309788608778)

Luo Y, Arnold J, Liu S, Wang X and Chen X (2012) Inclusion of glacier processes for distributed hydrological modeling at basin scale with application to a watershed in Tianshan Mountains, Northwest China. J. Hydrol., 477, 72-85 (doi: 10.1016/j. jhydrol.2012.11.005)

Lüthi MP (2009) Transient response of idealized glaciers to climate variations. J. Glaciol., 55(193), 918-930 (doi: 10.3189/ 002214309790152519)

Lutz AF, Immerzeel WW, Shrestha AB and Bierkens MFP (2014) Consistent increase in High Asia's runoff due to increasing glacier melt and precipitation. Nature Climate Change, 4, 587-592 (doi: 10.1038/nclimate2237)

Martinec J (1975) Snowmelt-runoff model for stream flow forecasts. Nordic Hydrol., 6, 145-154

Marzeion B, Jarosch AH and Hofer M (2012) Past and future sealevel change from the surface mass balance of glaciers. Cryosphere, 6, 1295-1322 (doi: 10.5194/tcd-6-1295-2012)

Matsuda Y, Fujita K, Ageta Y and Sakai A (2006) Estimation of atmospheric transmissivity of solar radiation from precipitation in the Himalayas and Tibetan Plateau. Ann. Glaciol., 43, 344-350

Mattson LE, Gardner JS and Young GJ (1993) Ablation on debris covered glaciers: an example from the Rakhiot Glacier, Punjab, Himalaya. IAHS Publ. 218 (Symposium at Kathmandu 1992 Snow and Glacier Hydrology), 289-296

Mitchell TD and Jones PD (2005) An improved method of constructing a database of monthly climate observations and associated high-resolution grids. Int. J. Climatol., 25, 693-712 (doi: 10.1002/joc.1181)

Moriasi DN, Arnold J, Liew MW, Bingner RL, Harmel RD and Veith TL (2007) Model evaluation guidelines for systematic quantification of accuracy in watershed simulations. Trans. Am. Soc. Agric. Biol. Eng., 50(3), 885-900

Moss RH and 18 others (2010) The next generation of scenarios for climate change research and assessment. Nature, 463(7282), 747-756 (doi: 10.1038/nature08823)

Nakawo M and Young GJ (1981) Field experiments to determine the effect of a debris layer on ablation of glacier ice. Ann. Glaciol., 2, 85-91

Nash JE and Sutcliffe JV (1970) River flow forecasting through conceptual models. Part 1. A discussion of principles. J. Hydrol., 10(3), 282-290

Neitsch SL, Arnold JG, Kiniry JR and Williams JR (2011) Soil and water assessment tool theoretical documentation version 2009. (Technical Report No. 406) Texas Water Resources Institute, College Station, TX

Nicholson L and Benn DI (2006) Calculating ice melt beneath a debris layer using meteorological data. J. Glaciol., 52(178), 463-470 (doi: 10.3189/172756506781828584)

Ohmura A (2001) Physical basis for the temperature-based meltindex method. J. Appl. Meteorol., 40, 753-761
Østrem G (1959) Ice melting under a thin layer of moraine and the existence of ice cores in moraine ridges. Geogr. Ann., 41, 228-230

Pan B and 7 others (2012) Glacier changes from 1966-2009 in the Gongga Mountains, on the south-eastern margin of the QinghaiTibetan Plateau and their climatic forcing. Cryosphere, 6, 1087-1101 (doi: 10.5194/tc-6-1087-2012)

Pu J (1994) Glacier Inventory of China VIII (the Changjiang River Drainage Basin). Gansu Culture Press, Lanzhou [in Chinese]

Radić V and Hock R (2011) Regionally differentiated contribution of mountain glaciers and ice caps to future sea-level rise. Nature Geosci., 4, 91-94 (doi: 10.1038/ngeo1052)

Radić V and Hock R (2014) Glaciers in the Earth's hydrological cycle: assessments of glacier mass and runoff changes on global and regional scales. Surv. Geophys., 35, 813-837 (doi: 10.1007/s10712-013-9262-y)

Radić V, Hock R and Oerlemans J (2008) Analysis of scaling methods in deriving future volume evolutions of valley glaciers. J. Glaciol., 54(187), 601-612 (doi: 10.3189/ 002214308786570809)

Rees HG and Collins DN (2006) Regional differences in response of flow in glacier-fed Himalayan rivers to climatic warming. Hydrol. Process., 20, 2157-2169 (doi: 10.1002/hyp.6209)

Reid TD, Carenzo M, Pellicciotti F and Brock BW (2012) Including debris cover effects in a distributed model of glacier ablation. J. Geophys. Res., 117(D18), D18105 (doi: 10.1029/ 2012JD017795)

Rignot E, Rivera A and Casassa G (2003) Contribution of the Patagonia Icefields of South America to sea level rise. Science, 302(5644), 434-437 (doi: 10.1126/science.1087393)

Sakai A, Fujita K, Nakawo M and Yao T (2009) Simplification of heat balance calculation and its application to the glacier runoff from the July 1 st Glacier in northwest China since the 1930s. Hydrol. Process., 23(4), 585-596 (doi: 10.1002/hyp.7187)

Scherler D, Bookhagen B and Strecker MR (2011) Hillslope glacier coupling: the interplay of topography and glacial dynamics in High Asia. J. Geophys. Res., 116(F2), F02019 (doi: 10.1029/ 2010JF001751)

Soil Conservation Service (SCS) (1972) Hydrology. In National engineering handbook. Soil Conservation Service, US Department of Agriculture, Washington, DC

Shi Y and Liu S (2000) Estimation on the response of glaciers in China to the global warming in the 21 st century. Chinese Sci. Bull., 45, 668-672

Sperna Weiland FC, Van Beek LPH, Kwadijk JCJ and Bierkens MFP (2010) The ability of a GCM-forced hydrological model to reproduce global discharge variability. Hydrol. Earth Syst. Sci., 14, 1595-1621 (doi: 10.5194/hess-14-1595-2010)

Su F, Duan X, Chen D, Hao Z and Cuo L (2013) Evaluation of the Global Climate Models in the CMIP5 over the Tibetan Plateau. J. Climate, 26, 3187-3208 (doi: 10.1175/JCLI-D-12-00321.1)

Su Z and Shi Y (2002) Response of monsoonal temperate glaciers to global warming since the Little Ice Age. Quat. Int., 97-98, 123-131

Su Z, Liu S, Wang N and Shi A (1992) Recent fluctuations of glaciers in the Gongga Mountains. Ann. Glaciol., 16, 163-167

Taylor KE, Stouffer RJ and Meehl GA (2012) An overview of CMIP5 and the experiment design. Bull. Am. Meteorol. Soc., 93, 485-498 (doi: 10.1175/BAMS-D-11-00094.1)

Van Beek LPH (2008) Forcing PCR-GLOBWB with CRU meteorological data. Utrecht University, Utrecht http://vanbeek.geo.uu. $\mathrm{nl} /$ suppinfo/vanbeek2008.pdf

Van Vuuren DP and 14 others (2011) The representative concentration pathways: an overview. Climatic Change, 109, 5-31 (doi: 10.1007/s10584-011-0148-z)

Yamazaki T, Kondo J, Sakuraoka T and Nakamura T (1993) A onedimensional model of the evolution of snow-cover characteristics. Ann. Glaciol., 18, 22-26

Yang W, Yao T, Xu B, Ma L, Wang Z and Wan M (2010) Characteristics of recent temperate glacier fluctuations 
in the Parlung Zangbo River basin, southeast Tibetan Plateau. Chinese Sci. Bull., 55, 2097-2102 (doi: 10.1007/s11434-0103214-4)

Yao T and 14 others (2012) Different glacier status with atmospheric circulations in Tibetan Plateau and surroundings. Nature Climate Change, 2, 663-667 (doi: 10.1038/nclimate1580)

Yatagai A, Arakawa O, Kamiguchi K, Kawamoto H, Nodzu MI and Hamada A (2009) A 44-year daily gridded precipitation dataset for Asia based on a dense network of rain gauges. SOLA, 5, 137-140 (doi: 10.2151/sola.2009-035)

Zhang Y, Liu S and Ding Y (2007) Glacier meltwater and runoff modelling, Keqicar Baqi glacier, southwestern Tien Shan, China. J. Glaciol., 53(180), 91-98 (doi: 10.3189/ 172756507781833956)
Zhang Y, Fujita K, Liu S, Liu Q and Wang X (2010) Multi-decadal ice-velocity and elevation changes of a monsoonal maritime glacier: Hailuogou glacier, China. J. Glaciol., 56(195), 65-74 (doi: 10.3189/002214310791190884)

Zhang Y, Fujita K, Liu S, Liu Q and Nuimura T (2011) Distribution of debris thickness and its effect on ice melt at Hailuogou Glacier, southeastern Tibetan Plateau, using in situ surveys and ASTER imagery. J. Glaciol., 57(206), 1147-1157 (doi: 10.3189/ 002214311798843331)

Zhang Y, Hirabayashi Y and Liu S (2012) Catchment-scale reconstruction of glacier mass balance using observations and global climate data: case study of the Hailuogou catchment, south-eastern Tibetan Plateau. J. Hydrol., 444-445, 146-160 (doi: 10.1016/j.jhydrol.2012.04.014)

MS received 29 September 2014 and accepted in revised form 1 May 2015 